\title{
Revision of the Poecilimon ornatus group (Orthoptera: Phaneropteridae) with particular reference to the taxa in Bulgaria and Macedonia*
}

\author{
Dragan P. CHOBANOV ${ }^{1}$ and Klaus-Gerhard HELLER ${ }^{2}$ \\ ${ }^{1}$ Institute of Biodiversity and Ecosystem Research, Bulgarian Academy of Sciences, 1 Tsar Osvoboditel blvd., \\ 1000 Sofia, Bulgaria; e-mail: dchobanov@gmail.com \\ ${ }^{2}$ Grillenstieg 18, 39120 Magdeburg, Germany; e-mail: heller.volleth@t-online.de
}

\begin{abstract}
Key words. Orthoptera, Phaneropteridae, Poecilimon, P. jablanicensis sp. n., systematics, bioacoustics, morphology, communication system, phylogeny, evolutionary trends, Balkan Peninsula

Abstract. The Poecilimon ornatus group has an exclusively European distribution and includes the largest species in the genus. A revision of the taxa belonging to this group in Bulgaria and Macedonia (Central and Eastern Balkan Peninsula) is presented. Nine taxa described from Bulgaria are synonymised with 3 previously known species, as follows: Poecilimon ornatus (= P. mistshenkoi marzani, syn. n., P. mistshenkoi tinkae, syn. n., P. mistshenkoi vlachinensis, syn. n.), P. affinis s. str. (= P. mistshenkoi mistshenkoi, syn. n., P. affinis ruenensis, syn. n., P. affinis rilensis, syn. n., P. affinis medimontanus, syn. n., $P$. harzi, syn. n.) and $P$. hoelzeli (= $P$. kisi, syn. n.). The synonymy of $P$. poecilus with $P$. affinis and the subspecific status of $P$. affinis komareki are confirmed. One species, Poecilimon jablanicensis, sp. n., is described as new to science. A tabulated key, lists and maps of all known localities and oscillograms of the songs of all the species in this group are presented. The phylogenetic relationships and evolutionary trends in the Poecilimon ornatus group are discussed.
\end{abstract}

\section{INTRODUCTION}

Poecilimon Fischer, 1853 is a group of short-winged herbivorous bushcrickets, distributed from the Apennines to Eastern Siberia and Central Tien-Schan (Bey-Bienko, 1954), and the largest genus of the suborder Ensifera in the Palaearctic. Its centre of speciation and diversity, however, is restricted to the Pontic region with only a few taxa occuring outside the Balkans, Asia Minor and the Caucasus region. They have poor dispersal ability due to their microptery and this along with the diverse geomorphological and climatic aspects and history of the area where they occur has resulted in rapid morphological and behavioural evolution. Within the genus there are many groups of apparently related taxa. Despite the few full or partial revisions (e.g. Ramme, 1933; Bey-Bienko, 1954; Willemse, 1982; Heller, 1984; Heller \& Lehmann, 2004; Heller \& Sevgili, 2005; Heller et al., 2006; Heller et al., 2008) the phylogeny and systematics of Poecilimon is only partly resolved. Even a recent partial review of the genus based on molecular data (Ullrich et al., 2010) has not clarified all questions.

One group for which the phylogeny and systematics is poorly known is the Poecilimon ornatus group. The species belonging here were listed in group I ("Gruppe I"; containing two sections) by Ramme (1933) in the first revision of the genus. The group's taxa are characterized by large or moderate body size, posteriorly widened and more or less upcurved pronotum, well visible tegmina and moderately incurved cerci with a single tooth. The Poecilimon ornatus-group after Heller (1984), consists of 8 taxa, namely $P$. nobilis Brunner von Wattenwyl, 1878, $P$. obesus obesus Brunner von Wattenwyl, 1878, P. obesus artedentatus Heller, 1984, P. affinis affinis (Frivaldszky, 1867), P. affinis komareki Čejchan, 1957, P. affinis hoelzeli Harz, 1966, P. ornatus (Schmidt, 1850) and P. pancici Karaman, 1958, distributed mainly in the Balkans. Later on, $P$. artedentatus and $P$. hoelzeli was given specific status (Willemse, 1985; Willemse \& Heller, 1992), $P$. pancici synonymised (Willemse, 1985) and a few new taxa, somewhat resembling the latter species, described ( $P$. pindos F. Willemse, 1982, P. soulion L. Willemse, 1987 and $P$. gracilioides F. Willemse et Heller, 1992). The last species connect the group morphologically with P. gracilis (Fieber, 1853). P. schmidtii (Fieber, 1853), forming together with $P$. gracilis the second section of Ramme's (1933) group I, is not closely related to the others (e.g. Ullrich et al., 2010) and is not included in this study. In this group, however, the following 9 taxa, described by Peshev (1980) from Bulgaria should be included: P. mistshenkoi mistshenkoi, P. mistshenkoi marani, P. mistshenkoi tinkae, P. mistshenkoi vlachinensis, $P$. affinis ruenensis, $P$. affinis rilensis, $P$. affinis medi-

\footnotetext{
* While this paper was in press, a study by Ingrisch and Pavicevic [2010; Seven new Tettigoniidae (Orthoptera) and a new Blattellidae (Blattodea) from the Durmitor area of Montenegro with notes on previously known taxa. Zootaxa 2565: 1-41] was published, also dealing with taxa of the $P$. ornatus group. The authors describe some new forms and change the rank of others. In contrast to the ideas presented in that paper we still consider the form $P$. rumijae as an infrasubspecific variation of $P$. affinis komareki. Judging from the extent of the differences we do not exclude the possibility that some of the newly described forms are local variants of $P$. affinis (compare with the morphological and bioacoustic variation described here).
} 
montanus, $P$. kisi and $P$. harzi. These forms, though described in detail, lack a well defined differential diagnosis and their taxonomic status and systematic relationships are still doubtful. After studying the type material and investigating the morphology, behaviour and bioacoustics of topotypic populations, some changes in the systematics and taxonomy of the group from Bulgaria became necessary. These taxa are the subject of the present work. The rest of the species in this group are restricted to Greece. Their distribution and systematic position have been studied by Willemse and co-authors (Willemse, 1982, 1985; Willemse \& Heller, 1992) and only the most important facts are repeated here for comparison. Due to the lack of song recordings for the two subspecies of $P$. affinis described by Karaman (1974), $P$. affinis serbicus Karaman, 1974 and P. affinis hajlensis Karaman, 1974, these taxa are not discussed in detail. In addition, during field studies, a new taxon from the Poecilimon ornatus group was discovered. While all other species of the group have a bidirectional soundcommunication system (ancestral condition in Poecilimon), this species possesses a unidirectional acoustic communication system (loss of female tegmina together with stridulatory organs). This new species, Poecilimon jablanicensis, sp. n., is described and some conclusions about the evolutionary trends in the group are presented in this paper.

\section{MATERIAL AND METHODS}

During the present study material from several collections were surveyed, including the National Museum of Natural History (at that time containing also the former collection of Orthoptera of the Institute of Zoology), Bulgarian Academy of Sciences, Sofia; collection of the Natural History Section of the Regional History Museum in Blagoevgrad; collection of the Macedonian Museum of Natural History, Skopje; collection of Dragan Chobanov; collection of Klaus-Gerhard Heller, abbreviated as $\mathrm{NMNH}, \mathrm{HMB}, \mathrm{MMNH}, \mathrm{CC}$ and $\mathrm{CH}$, respectively. In addition, material from some private collections was examined.

Concerning the systematics and distribution of species only references with original or supplementary information are presented. For each taxon a distributional map is prepared including both literature (localities revised when material available) and unpublished data. Data on altitude were added, if missing, using the co-ordinates and the GPSVisualizer online (Scheider; www.gpsvisualizer.com).

Songs of the species investigated were recorded with an electret condenser microphone (Knowles BT-1759-000) equipped with a custom-made preamplifier, connected to a $\mathrm{PC}$ through an external soundcard (TransitUSB, "M-Audio") (96 kHz sampling rate). Song measurements were obtained manually in WaveLab5 (Steinberg). For the spectrum of $P$. jablanicenis (due to a reduced sampling rate of $48 \mathrm{kHz}$ only up to $24 \mathrm{kHz}$ ) the response curve of the Knowles microphone was corrected using a comparison with a Brüel \& Kjaer 4133 microphone. Recordings were processed and oscillograms of the songs were prepared using Turbolab 4.0 (Bressner Technology, Germany). The recordings for the comparative figures were made using different types of equipment. For sound recording in the field most often a Uher tape recorder 4200 IC with a Uher M645 microphone (frequency response flat up to $20 \mathrm{kHz}$ ) and in the laboratory a Racal store 4 D tape recorder with Brüel \& Kjaer 4133 and 4135 microphones (frequency response flat up to 40 , respectively $70 \mathrm{kHz}$ ), were used.

Bioacoustic terminology: calling song - the song produced by an isolated male; syllable - the sound produced by one openingand-closing movement of the tegmina; syllable duration - the time measured from the beginning of the first to the end of last impulse in a syllable; syllable period - the span including a syllable and the following interval; impulse - a undivided transient train of sound waves produced by the stridulatory tooth striking the plectrum (the anal edge of the opposite tegmen).

Appendix with detailed distribution of individual species is available online at:

$<$ http://www.eje.cz/supplfiles/eje1575suppl.pdf $>$

\section{RESULTS}

\section{A. Species of the Poecilimon ornatus group occurring in Bulgaria and Macedonia}

All species in this group on the Central and Eastern Balkan Peninsula and adjacent territories in the North fall into two groups: either large and bulky animals or small and slender ones (see Table 2). The first group can morphologically (and by song) be separated into three subgroups, which are considered here to be three separate species (although they rarely occur sympatrically or syntopically), $P$. ornatus, $P$. affinis and $P$. hoelzeli. The second is made up of two distinct species, one widespread (P. gracilis) and one very local, which is a new species.

\section{Poecilimon ornatus (Schmidt, 1850)}

Ephippigera ornata Schmidt, 1850 (184), type locality Slovenia [northern part = S Kärnten, Kamnik (see Willemse, 1985)].

Barbitistes fieberi Fieber, 1853 (175), type locality Italy, Trieste; synonymized with $P$. ornatus by Krauss (1878); Brunner von Wattenwyl $(1878,1882)$ used the younger name fieberi including P. ornatus.

Odontura ornata; Schmidt, 1866 (81).

Poecilimon ornatus; Krauss, 1878 (497); Ramme, 1933 (511, Pl. 6, Fig. 2., Pl. 7, Fig. 1, Pl. 8, Fig. 1, Pl. 11, Fig. 1, P1. 12, Fig. 1); Bey-Bienko, 1954 (270-271); Harz, 1969 (119-120, Figs 32, 268, 270, 271, 319, 322); Willemse, 1982 (partim; 156-158, Figs 1, 2, 5, 9); Heller, 1984 (83, 85, Figs 5-D, 7-E-G, 9-B); Willemse, 1985 (11-12, Figs 1-5, 34); Heller, 1988 (50-51, Pls 34-G, 88, 120-D).

Poecilimon pancici Karaman, 1958 (36, Figs 1-7), type locality Macedonia, Gradishtanska Planina Mt., Gabresh vill.; Harz, 1969 (122); Willemse, 1982 (158, Fig. 10). Synonym of $P$. ornatus after Heller (1988).

Poecilimon greini Harz, 1977 (27-28). Synonym of P. ornatus after Heller (1984).

Poecilimon mistshenkoi marzani Peshev, 1980 (33-34), type locality Bulgaria, Alibotush Mt., Kosharite Locality, 1800-1900 m, syn. n.

Poecilimon mistshenkoi tinkae Peshev, 1980 (34), type locality Bulgaria, Belassitsa Mt., northeastern slope of Kalabak Peak, 1700 m, syn. n.

Poecilimon mistshenkoi vlachinensis Peshev, 1980 (34, 36), type locality Bulgaria, Vlakhina Mts, eastern slope, near the state boundary between Yugoslavia and Bulgaria, 1600-1700 m [Kadiytsa Peak], syn. n.

Variation (general appearance - Fig. 1A). The populations from different parts of the range and different altitudes vary significantly in body size and colouration (compare Fig. 1J and 1K). Generally, the melanistic col- 
TABle 2. Tabulated key for distinguishing the species of the Poecilimon ornatus group.

\begin{tabular}{|c|c|c|c|c|c|c|c|c|c|c|c|}
\hline $\begin{array}{l}\text { species / } \\
\text { character }\end{array}$ & $\begin{array}{l}\text { auditory } \\
\text { spiracle }\end{array}$ & $\begin{array}{l}\text { female } \\
\text { tegmina }\end{array}$ & $\begin{array}{c}\text { male cerci } \\
(\text { see Figs } 2,3)\end{array}$ & $\begin{array}{l}\text { metazona } \\
\text { of male } \\
\text { pronotum }\end{array}$ & $\begin{array}{l}\text { hind } \\
\text { femur } \\
\text { length } \\
(\mathrm{mm})\end{array}$ & $\begin{array}{l}\text { stridula- } \\
\text { tory file } \\
\text { shape }\end{array}$ & $\begin{array}{l}\text { stridulatory } \\
\text { teeth } \\
\text { distribution }\end{array}$ & $\begin{array}{l}\text { stridula- } \\
\text { tory teeth } \\
\text { number }\end{array}$ & $\begin{array}{l}\text { syllables } \\
\text { shape }\end{array}$ & $\begin{array}{c}\text { syllable } \\
\text { duration } \\
\left(20-30^{\circ} \mathrm{C}\right)\end{array}$ & $\begin{array}{c}\text { distribution } \\
\text { (see Figs } 10, \\
11,12,13)\end{array}$ \\
\hline $\begin{array}{l}\text { P. jablani- } \\
\text { censis }\end{array}$ & small & $\begin{array}{l}\text { small, non- } \\
\text { overlapping }\end{array}$ & $\begin{array}{c}>2.5 \mathrm{~mm}, \\
\text { tooth distinct }\end{array}$ & $\begin{array}{l}\text { strongly } \\
\text { raised } \\
\text { fig. } 8 \mathrm{C}\end{array}$ & $11.5-14.0$ & arcuate & $\begin{array}{l}\text { size evenly } \\
\text { decreasing }\end{array}$ & 10 & $\begin{array}{c}\text { compact, } \\
\text { cres- } \\
\text { cendo }\end{array}$ & $\begin{array}{c}>350- \\
\sim 1000 \mathrm{~ms}\end{array}$ & $\begin{array}{l}\text { Jablanica Mt. } \\
\text { SW Macedonia }\end{array}$ \\
\hline P. gracilis & large & overlapping & $\begin{array}{l}>2.5 \mathrm{~mm} \\
\text { tooth distinct }\end{array}$ & $\begin{array}{l}\text { strongly } \\
\text { raised }\end{array}$ & $11.5-18.5$ & arcuate & $\begin{array}{l}\text { size evenly } \\
\text { decreasing }\end{array}$ & $135-160$ & bipartite & $\begin{array}{c}>250-400 \\
\mathrm{~ms}\end{array}$ & $\begin{array}{l}\text { W \& NW Bal- } \\
\text { kans to Austria }\end{array}$ \\
\hline $\begin{array}{l}P . \text { gra- } \\
\text { cilioides }\end{array}$ & large & overlapping & $\begin{array}{l}<2.5 \mathrm{~mm} \text {, } \\
\text { tooth distinct }\end{array}$ & $\begin{array}{l}\text { strongly } \\
\text { raised }\end{array}$ & $14.3-15.6$ & te & $\begin{array}{l}\text { size abruptly } \\
\text { decreasing at } \\
2 / 3 \text { from base }\end{array}$ & $\sim 120$ & tripartite & $>25$ & NW Greece \\
\hline P. soulion & large & overlapping & $\begin{array}{c}<2.5 \mathrm{~mm}, \\
\text { tooth distinct }\end{array}$ & $\begin{array}{l}\text { slightly } \\
\text { raised }\end{array}$ & $17.0-19.2$ & arcuate & $\begin{array}{l}\text { size abruptly } \\
\text { decreasing at } \\
2 / 3 \text { from base }\end{array}$ & $\sim 140$ & tripartite & $\begin{array}{c}300-650 \\
\mathrm{~ms}\end{array}$ & $\begin{array}{c}\text { Mountains in } \\
\text { Pindos range, } \\
\text { Greece }\end{array}$ \\
\hline P. nobilis & large & overlapping & $\begin{array}{l}<2 \mathrm{~mm} \text {, } \\
\text { tooth distinct }\end{array}$ & $\begin{array}{l}\text { slightly } \\
\text { raised }\end{array}$ & $15.5-18.0$ & arcuate & $\begin{array}{l}\text { size evenly } \\
\text { decreasing }\end{array}$ & -120 & bipartite & $\begin{array}{c}\sim 500-800 \\
\mathrm{~ms}\end{array}$ & $\begin{array}{l}\text { Peloponnesos } \\
\text { (S Greece) }\end{array}$ \\
\hline P. obesus & large & overlapping & $\begin{array}{l}>2.5 \mathrm{~mm}, \\
\text { tooth distinct }\end{array}$ & $\begin{array}{l}\text { slightly } \\
\text { raised }\end{array}$ & $21.0-23.0$ & arcuate & $\begin{array}{c}\text { size slightly } \\
\text { decreasing at the } \\
\text { very apex }\end{array}$ & $\sim 120$ & bipartite & $\begin{array}{c}>500-1000 \\
\mathrm{~ms}\end{array}$ & $\begin{array}{l}\text { W Continental } \\
\text { Greece (W \& S } \\
\text { Greece) }\end{array}$ \\
\hline $\begin{array}{l}P . \text { arteden- } \\
\text { tatus }\end{array}$ & large & overlapping & $\begin{array}{l}>2.5 \mathrm{~mm} \\
\text { tooth distinct }\end{array}$ & $\begin{array}{l}\text { slightly } \\
\text { raised }\end{array}$ & $18.3-22.0$ & arcuate & $\begin{array}{l}\text { size very gently } \\
\text { decreasing }\end{array}$ & $\sim 280$ & $\begin{array}{l}\text { compact, } \\
\text { cres- } \\
\text { cendo }\end{array}$ & $>\sim 500 \mathrm{~ms}$ & $\begin{array}{r}\text { Pelopo } \\
(\mathrm{S} \mathrm{Gr}\end{array}$ \\
\hline P. pindos & large & overlapping & $\begin{array}{l}<2.5 \mathrm{~mm}, \\
\text { tooth indistinct }\end{array}$ & $\begin{array}{l}\text { slightly } \\
\text { raised }\end{array}$ & $15.1-18.2$ & arcuate & $\begin{array}{l}\text { size very gently } \\
\text { decreasing }\end{array}$ & $115-135$ & $\begin{array}{l}\text { compact, } \\
\text { cres- } \\
\text { cendo }\end{array}$ & $\begin{array}{c}>100-150 \\
\mathrm{~ms}\end{array}$ & $\begin{array}{c}\text { N Pindos range } \\
\text { (NW Greece) }\end{array}$ \\
\hline P. hoelzeli & large & overlapping & $\begin{array}{l}=2.5 \mathrm{~mm}, \\
\text { tooth indistinct }\end{array}$ & $\begin{array}{l}\text { strongly } \\
\text { raised }\end{array}$ & $16.5-21.0$ & Ircuate & $\begin{array}{l}\text { size very gently } \\
\text { decreasing }\end{array}$ & -270 & $\begin{array}{c}\text { compact, } \\
\text { cres- } \\
\text { cendo }\end{array}$ & $\begin{array}{c}>100-150 \\
\mathrm{~ms}\end{array}$ & $\begin{array}{l}\text { S Macedonia, } \\
\text { SW Bulgaria } \\
\text { and N Greece }\end{array}$ \\
\hline $\begin{array}{l}\text { P. affinis } \\
\text { affinis }\end{array}$ & large & overlapping & $\begin{array}{l}>2.5 \mathrm{~mm}, \\
\text { tooth indistinct }\end{array}$ & $\begin{array}{l}\text { strongly } \\
\text { raised } \\
\text { (variable) }\end{array}$ & $13.0-25.0$ & $\begin{array}{l}\text { slightly } \\
\text { bulged in } \\
\text { the middle }\end{array}$ & $\begin{array}{l}\text { size evenly } \\
\text { decreasing }\end{array}$ & $180-240$ & $\begin{array}{c}\text { compact, } \\
\text { cres- } \\
\text { cendo }\end{array}$ & $\begin{array}{c}>100-500 \\
\mathrm{~ms}\end{array}$ & $\begin{array}{c}\text { N \& C Balkans } \\
\text { and Carpa- } \\
\text { thians }\end{array}$ \\
\hline $\begin{array}{l}\text { P. affinis } \\
\text { komareki }\end{array}$ & large & overlapping & $\begin{array}{l}>3 \mathrm{~mm}, \\
\text { tooth indistinct }\end{array}$ & $\begin{array}{l}\text { strongly } \\
\text { raised } \\
\text { (variable) }\end{array}$ & $21.0-25.0$ & $\begin{array}{l}\text { slightly } \\
\text { bulged in } \\
\text { the middle }\end{array}$ & $\begin{array}{l}\text { size evenly } \\
\text { decreasing }\end{array}$ & $\sim 250$ & $\begin{array}{c}\text { compact, } \\
\text { cres- } \\
\text { cendo }\end{array}$ & $\begin{array}{l}\text { within the } \\
\text { range of } P \text {. } \\
\text { a. affinis }\end{array}$ & $\begin{array}{l}\text { Coastal } \\
\text { Albania and } \\
\text { Montenegro }\end{array}$ \\
\hline P. ornatus & large & overlapping & $\begin{array}{l}>3 \mathrm{~mm}, \\
\text { tooth indistinct }\end{array}$ & $\begin{array}{l}\text { strongly } \\
\text { raised } \\
\text { (variable) }\end{array}$ & $19.0-24.0$ & $\begin{array}{l}\text { distinctly } \\
\text { bulged in } \\
\text { the distal } \\
\text { part }\end{array}$ & $\begin{array}{l}\text { size decreasing } \\
\text { after the bulge }\end{array}$ & $158-220$ & $\begin{array}{c}\text { compact, } \\
\text { rectan- } \\
\text { gular }\end{array}$ & $<50 \mathrm{~ms}$ & $\begin{array}{l}\text { C \& NW Bal- } \\
\text { kans to Austria } \\
\text { and Italy }\end{array}$ \\
\hline
\end{tabular}

ouration varies within a population, while there is a tendency for body size to be smaller at higher altitudes (see Discussion). The pronotal shape, mostly the elevation of the metazona, and the part of the tegmina covered by the pronotum vary even between animals from the same place. Strongly raised metazona of pronotum and strong development of a melanistic colouration are also observed in animals from high-density populations. All these characters cannot be used as distinctive. The cercus shape may be a better character, the cerci being gently incurved at the ends, but here also there can be confusion with $P$. affinis (compare Figs 2O1-O10 and 3A1-A14). The most stable morphological feature is the shape of the stridulatory file (Heller, 1984; Willemse, 1985) (Figs 4 and 5: O1-O3), which has a distinct bulge distally. The number of stridulatory teeth also varies considerably, though there are generally fewer teeth than in $P$. affinis. Heller (1988) reports $158-212$ stridulatory teeth in $P$. ornatus, which is well supported by new observations, with some large specimens having up to 220 teeth. Usually the number of teeth does not exceed 200. The song (Figs 6O1, O2, 7B) is the most striking characteristic of this species, consisting of very short syllables with high amplitude from the abrupt beginning to the end (often with a longer, lowamplitude fading end resulting from echoes). The syllable lasts only about $10 \mathrm{~ms}$ and even with echoes it is still much shorter than $100 \mathrm{~ms}$. The female responds to the male song $40 \mathrm{~ms}$ after its beginning (at $30^{\circ} \mathrm{C}$; Heller et al., 1997) and the male song must have ended if it is to hear her response. Also the stridulatory movement is much faster and shorter than in all other species of the group (Heller, 1988).

Synonymy. The two sibling species, $P$. ornatus and $P$. affinis, vary greatly throughout their range (horizontally and altitudinally) in morphological features, which previously were thought to be distinctive (e.g. Ramme, 1951; Harz, 1969; Karaman, 1974; Willemse, 1984), e.g. width of fastigium in relation to scapus, pronotal and cercal shape, general body size, etc. Heller (1984) shows that the definition of both species and their relatives on the basis of these characters is often unreliable. He (1.c.) also indicates that the song and structure of the stridulatory file are stable characters that can be reliably used to differentiating between the species in the Poecilimon ornatus group, and this was confirmed by subsequent studies (e.g. Willemse, 1985; Heller, 1988). Some valuable differences in the shape of the cercus were pointed out by Willemse (1985), but there is overlap between species (see "Variation"; P. affinis; Figs 2, 3). 

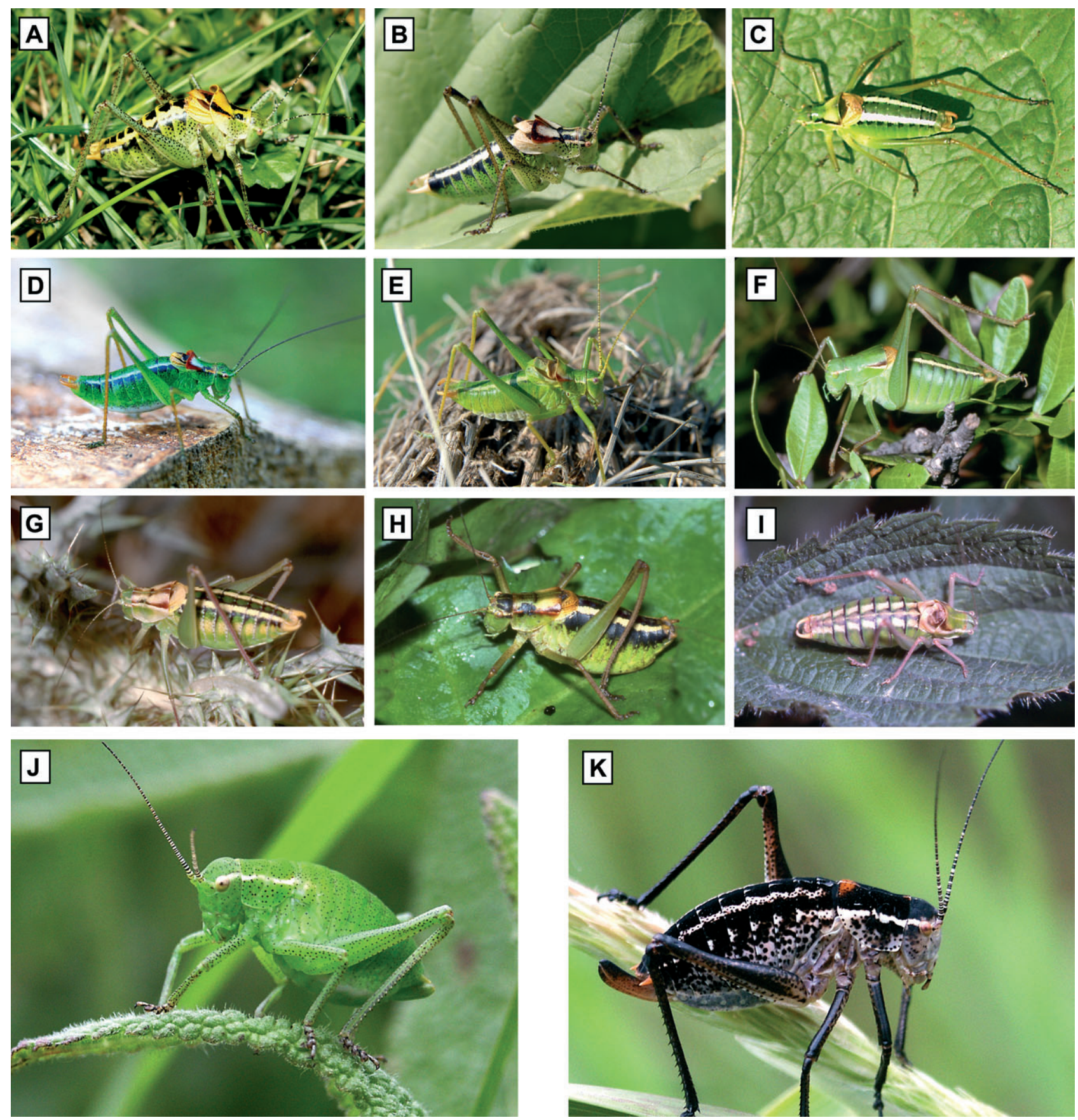

Fig. 1. Appearance of some of the species of the Poecilimon ornatus group (relative sizes of the species not maintained). A $-P$. ornatus, Bulgaria, Alibotoush, $1750 \mathrm{~m}$ (M. Langourov); B - P. affinis, Macedonia, Shar, $1800 \mathrm{~m}$ (L. Stefanov); C - P. hoelzeli, Macedonia, Kozhuf, 1750 m; D - P. gracilis, Macedonia, Shar, 1400 m (L. Stefanov); E - P. jablanicensis, Macedonia, Jablanica, 1800-1950 m; F - P. obesus, Greece; G - P. artedentatus, Greece; H - P. nobilis, Greece; I - P. gracilioides, Greece; J - P. ornatus (nymph from a low-density population), Macedonia, Mariovo (L. Stefanov); K - P. ornatus (nymph from a high-density population), Macedonia, Mariovo (L. Stefanov).

In his study on Poecilimon, Peshev (1980) describes nine new taxa (including species and subspecies) in the Poecilimon ornatus group from Bulgaria. The morphological descriptions, though detailed, are insufficient for the determination of even abundant material. The short differential diagnoses are based mostly on pronotal shape and relative proportions of tegmina, cerci, genital plate and ovipositor, which are unreliable taxonomic features in this group (see above; Heller, 1984; Willemse, 1985), especially in comparison with $P$. affinis. Peshev (1980) emphasized the similarity of $P$. mistshenkoi and $P$. ornatus without citing well defined differences. Study of material from various localities showed that the morphological features characterizing $P$. ornatus, like the shape of the cercus (Fig. 2O1-O10) and stridulatory file (Figs 4 and 5: O1-O3), are present in specimens from well defined regions in Bulgaria and Macedonia, connected with the species' range in neighbouring territories in 

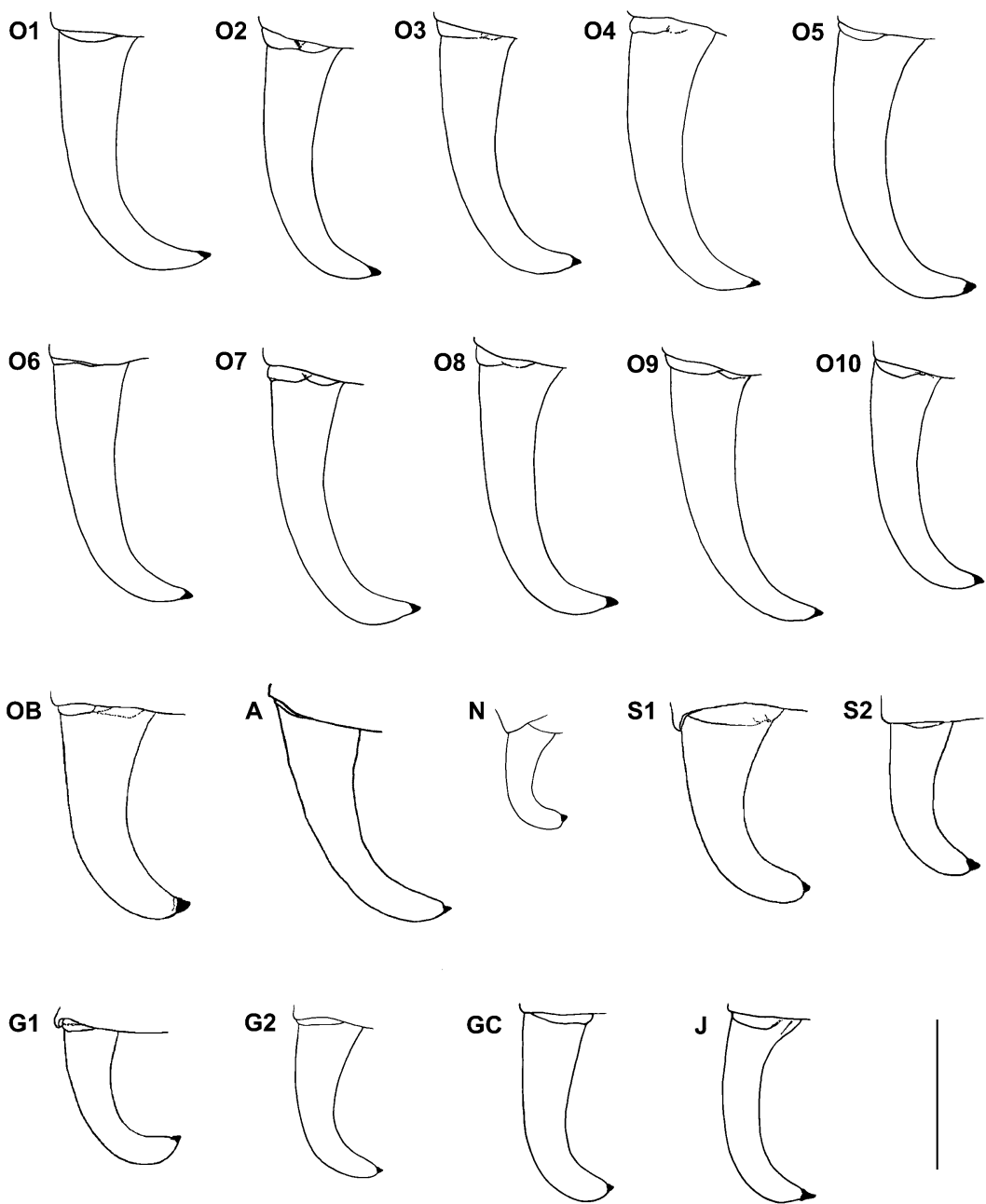

Fig. 2. Poecilimon ornatus group, dorsal view of male cercus: O1-O10 - P. ornatus $(\mathrm{O} 1$ - Bulgaria, Pirin, Demir Kapiya Pass, 1800 m; O2 - Bulgaria, Pirin, Begovishki Rid Ridge, 2200 m; O3 - Bulgaria, Pirin, Pirin Chalet, 1700 m; O4 - Bulgaria, Pirin, Orelek Peak; O5 - Bulgaria, Alibotoush, 1750 m; O6 - Bulgaria, Belassitsa, 1700-1900 m; O7 - Bulgaria, Ograzhden, 1500 m; O8 - Bulgaria, Maleshevska Planina; O9 - Bulgaria, Vlakhina, 1600-1900 m; O10 - Macedonia - Jakupica); OB - P. obesus, Greece, Koutsilaris, 200 m, CH2938; A - P. artedentatus, Greece, Peloponnesos, Metaxion, 840 m; N - P. nobilis, Greece, Peloponnesos, Mainalon (redrawn from Willemse, 1987); S1 - P. soulion, Greece, Tomaros, 900-1900 m, CH6510; S2 - P. soulion, Greece, Timfristos, CH2475; G1 - P. gracilioides, Greece, Tsoumerka, 1850 m, CH6921; G2 - P. gracilioides, Greece, Karava Range; GC - P. gracilis, Macedonia, Radika, $900 \mathrm{~m}$; J $-P$. jablanicensis, Jablanica, $1850 \mathrm{~m}$. Scale $=2 \mathrm{~mm}$.

Greece. The latter is true both for the type material and newly collected specimens from the type localities and known distributional range of $P$. mistshenkoi marzani, $P$. mistshenkoi tinkae, $P$. mistshenkoi vlachinensis and populations from reported localities of $P$. mistshenkoi mistshenkoi (see P. affinis). Song analysis (see Fig. 4O1, $\mathrm{O} 2$ ) proved these taxa clearly belong to $P$. ornatus and support the proposed synonymy.

Distribution (Figs 10, 11, Appendix). In the literature before Heller (1984) and even later, P. ornatus is frequently confused with $P$. affinis, thus many records will remain doubtful until the collected material is revised or until new material is collected in the respective localities. This is epecially true for some territories in Bosnia and Hercegovina, Serbia, Montenegro and Albania.

The species' range covers the western half of the Balkan Peninsula (Northwestern Greece - North of Tsoumerka Mt., Southwestern Bulgaria, Central and Eastern Macedonia, Montenegro, Bosnia and Hercegovina, Croatia, Slovenia) and the easternmost part of the Alps (Italy and Austria). Interestingly the range appears to be divided into a northern (from Austria to Montenegro) and southern part (south- and eastwards of Central Macedonia) separated by a gap. This gap is probably the result of less intensive collecting in this area as it is recorded in other species, e.g. Eupholidoptera chabrieri (Ciplak et al., 2007). In addition, associated with this gap is the serious problem of this species being misidentified as $P$. affinis. There are no obvious differences between the northern and the southern populations. The range of the southern population covers the easternmost edge of the Pindo-Dinaric mountain group, including the mountains of the Northern Vardar zone (e.g. Vodno) and the eastern part of the Pelagonian horst anticline (Yakupitsa, Babuna, Goleshnitsa etc. in Macedonia), dipping into the southwestern part of the Rhodope group (the bordering mountains of Vlakhina, Maleshevska, Ograzhden, Belassitsa, as well as Pirin, Alibotush, Vrontou and Pangaion in Bulgaria and Greece). Further southwestwards there is another gap, separating a small population in Northwestern Greece (the mountains of Smolikas and Tzoumerka). 

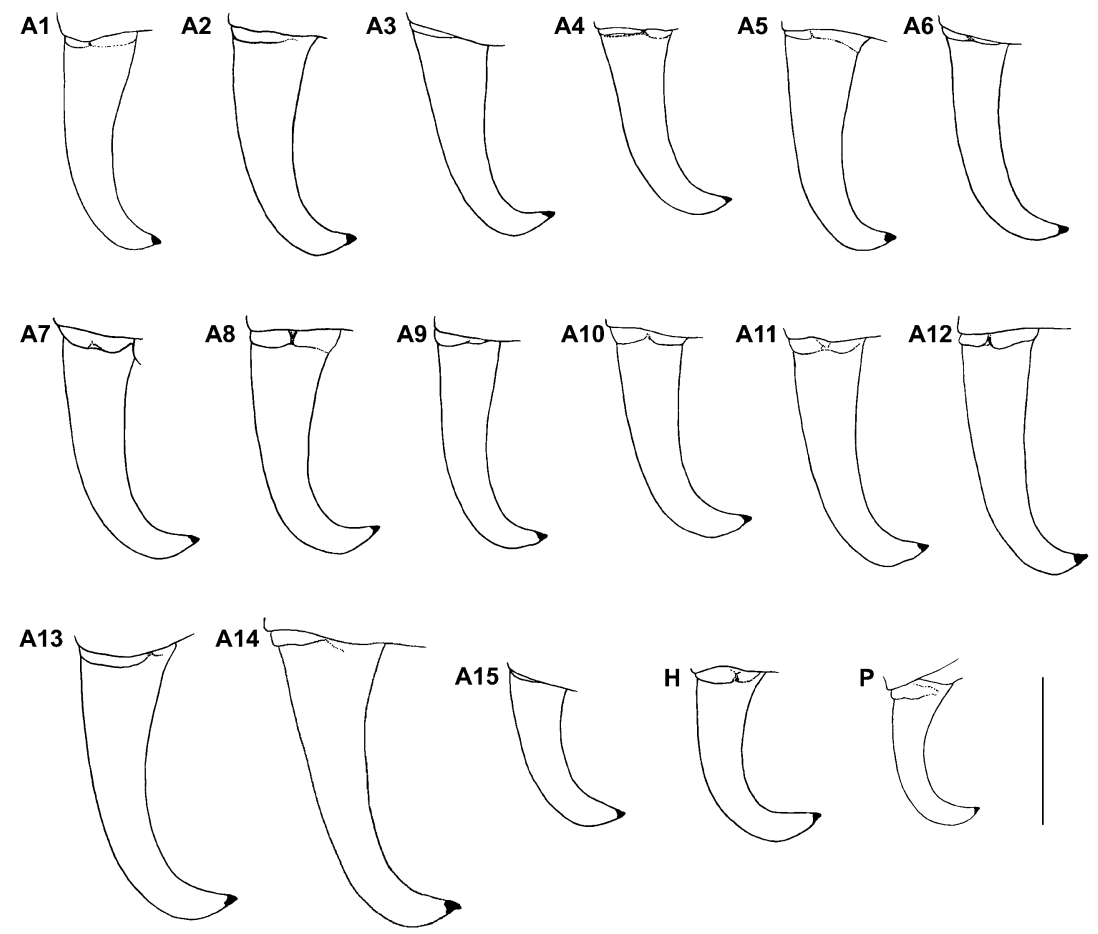

Fig. 3. Poecilimon ornatus group, dorsal view of male cercus: A1-A13 - P. affinis affinis (A1 - Bulgaria, W Stara Planina, Kom Peak, 1500 m; A2 - Bulgaria, Sredna Gora, Bratiya Peak, 1450 m; A3 - Bulgaria, Ossogovska Planina, Tri Bouki Hotel, 1400-1600 m; A4 - Bulgaria, Rila, Parangalitsa Reserve, >1900 m, A5 - Bulgaria, Rila, Septemvriyche Resort; A6 - Bulgaria, Pirin, Sedelets Peak, 1700-1900 m; A7 - Bulgaria, Pirin, Pirin Peak; A8 - Bulgaria, Pirin, Dautov Vruh Peak; A9 - Bulgaria, Pirin, Dzhindzhiritsa Cirque; A10 - Bulgaria, Pirin, Byala Reka Reserve; A11 - Bulgaria, Pirin, Bayuvi Doupki Reserve; A12 - Bulgaria, Pirin, Strazhite Peak; A13 - Macedonia, Radika Valley, 900 m); A14 - P. affinis komareki, Montenegro, Rumija, CH1128; A15 - P. cf. affinis, Montenegro, Durmitor; H - P. hoelzeli - Bulgaria, Belassitsa, 1700-1900 m; P - P. pindos, Greece, Timfi (redrawn from Willemse, 1987). Scale $=2 \mathrm{~mm}$.

\section{Poecilimon affinis (Frivaldszky, 1867)}

$P$. affinis has the largest range of the taxa within this group. It extends from Northern Greece to the Carpathians in Romania and covers a relatively compact area. An isolated locality is known from the Ukraine. All over this range, the species exhibits nearly no differences in song pattern and the morphological variation is mainly connected with altitude (see below). As a result of this variation, many subspecies are described based on subtle differences (see under $P$. affinis affinis). Although generally a mountainous species, one population has adapted to living in Mediterranean scrub along the Adriatic coast of Northern Albania and Montenegro. Though retaining the same song characteristics, these animals are significantly larger and much stouter than those in most other populations of the species. This population was described by Čejchan (1957) as a distinct species, P. komareki, but Heller (1984) regarded it as a subspecies of $P$. affinis because of its great similarity with the latter. Revision of the available material and song recordings, and taking into account the poorly investigated transitional populations between typical $P$. affinis and the coastal populations, indicates that the species $P$. affinis consists of two subspecies.

\section{Poecilimon affinis affinis (Frivaldszky, 1867)}

Odontura affinis Frivaldszky, 1867 (91, Fig. 2), type locality SW Romania, Mehadia.
Poecilimon affinis; Brunner von Wattenwyl, 1878 (37, 39); Ramme, 1933 (512, Pl. 6, Fig. 1., Pl. 8, Fig. 2, Pl. 11, Fig. 2, Pl. 12, Fig. 2); Bey-Bienko, 1954 (273-274); Harz, 1969 (121, Figs 275, 276, 321, 354, 355-358).

Poecilimon poecilus Ramme, 1951 (94-95), type locality Macedonia, Shar Mts, Popova Shapka resort, $2000 \mathrm{~m}$. Synonym of P. affinis affinis after Heller (1984).

Poecilimon affinis poecilus; Karaman, 1974 (27-29, Figs 4-6, 12, 17, 20, 22, 23, 29, 30, 36).

Poecilimon ornatus (Schmidt); Willemse, 1984 (partim; 156, Figs 3, 4, 6-8, 199, 200).

Poecilimon affnis s. str.; Heller, 1984 (82, Figs 5-C, 7-D, 8-A, 9-A); Willemse, 1985 (12-14, Figs 6-10, 35); Heller, 1988 (48-49, Pls 34-E, 35-D, 88, 120-C).

Poecilimon mistshenkoi mistshenkoi Peshev, 1980 (30-33), type locality Bulgaria, Pirin Mts, along the road from the town of Bansko to the Bunderitsa tourist hostel, about 1600 m, syn. n. Poecilimon affinis affinis (Friv.): Peshev, 1980 (37-39).

Poecilimon affinis ruenensis Peshev, 1980 (39), type locality Bulgaria, Ossogovo Mts, the foot of Ruen Peak, Kolonite Locality, 1560 m, syn. n.

Poecilimon affinis rilensis Peshev, 1980 (39-40), type locality Bulgaria, Rila Mts, the valley of Rilska River, 1600 m, syn. n. Poecilimon affinis medimontanus Peshev, 1980 (40), type locality Bulgaria, Sredna Gora Mt., Bratia Peak, 1450 m, syn. n.

Poecilimon harzi Peshev, 1980 (41-42), type locality Bulgaria, Pirin Mts, Suhodol Locality, near Yavorov tourist hostel, $1750 \mathrm{~m}$, syn. n. 

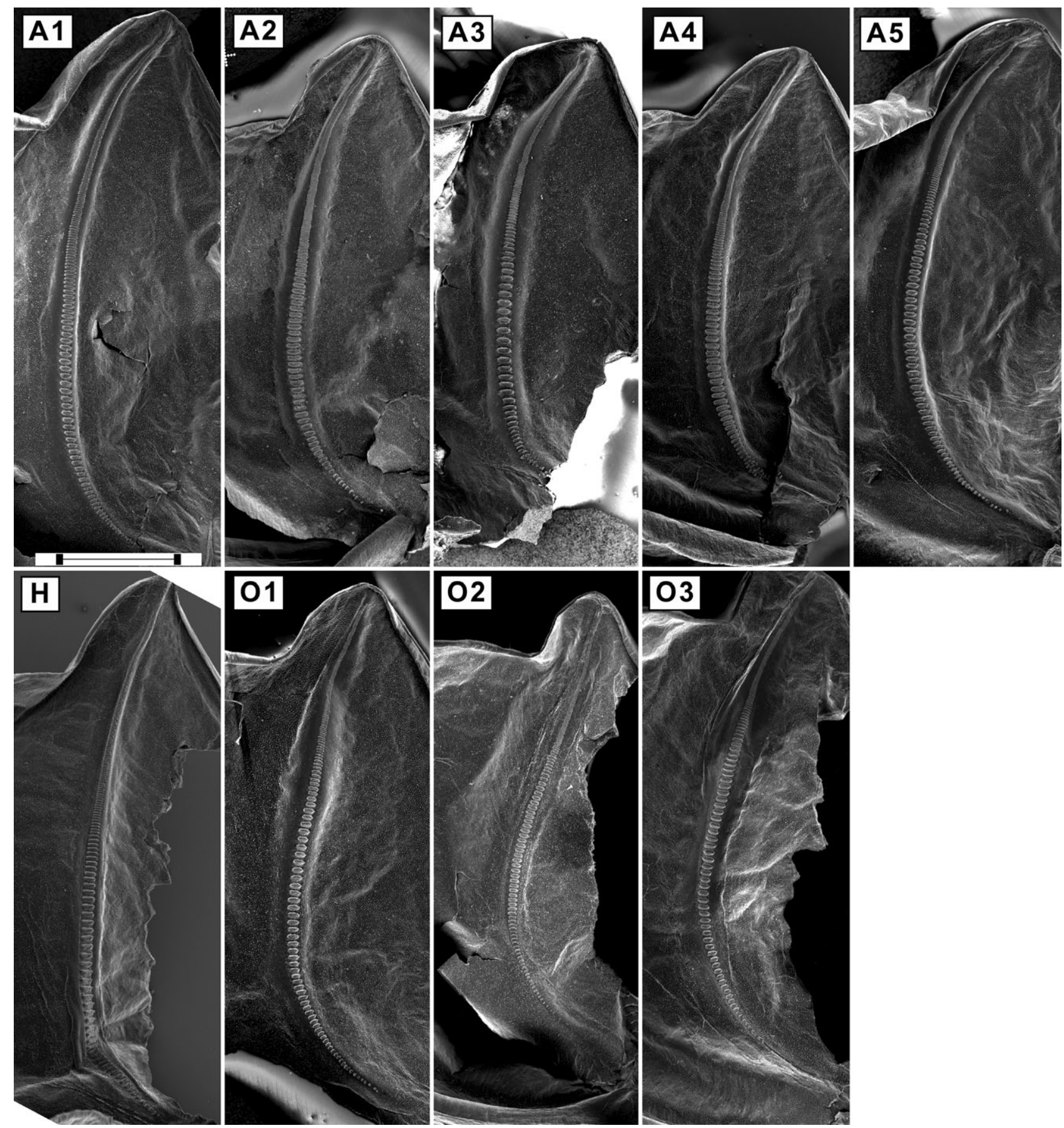

Fig. 4. SEM-photographs of the stridulatory files of P. affinis (A1-A5), P. hoelzeli (H) and P. ornatus (O1-O3) from Bulgaria: A1 - paratype of $P$. affinis medimontanus, Sredna Gora Mts, Bratiya peak, 1400-1500 m, 23.vii.1973, Peshev leg. (NMNH), 220 stridulatory teeth; A2 - paratype of P. affinis ruenensis, Ossogovo Mts, 1335-1550 m, 3.viii.1974, Andreeva leg. (NMNH); A3 Andreeva det. as $P$. affinis rilensis, Rila Mts, Parangalitsa Preserve, 12.ix.1980, Andreeva leg. (NMNH), 180 stridulatory teeth; A4 topotype of $P$. harzi, Pirin Mts, Byala Reka Preserve, 14.viii.1986, Andreeva leg. (NMNH); A5 - topotype of $P$. mistshenkoi mistshenkoi, Pirin Mts, Bunderitsa chalet, 1850 m, 22.vii.2001, Chobanov \& Heller leg. (CC), 200-210 stridulatory teeth; H - paratype of P. kisi, Belassitsa Mt., Demir Kapiya pass, 1800 m, 25.vii.1977, Slaveykov leg. (NMNH), 250-255 stridulatory teeth; O1 topotype of $P$. mistshenkoi marani, Alibotoush Mt., Livade place, 1700 m, 9.viii.2006, Chobanov leg. (CC); O2 - paratype of $P$. mistshenkoi tinkae, Belassitsa Mt., Demir Kapiya pass, 1800 m, 23.vii.1977, Slaveykov leg. (NMNH); O3 - syntype of $P$. mistshenkoi vlachinensis, Vlakhina Mts, 1700-1900 m, 31.vii.1974, Andreeva leg. (NMNH). Scale = $1 \mathrm{~mm}$.

\section{Poecilimon affinis komareki Čejchan, 1957}

Poecilimon komareki Čejchan, 1957 (5, Figs 1-5), type locality Albania, Linze near Tirana; Harz, 1969 (121-122, Figs 274, 277). Subspecies of $P$. affinis after Heller (1984).
Poecilimon komareki rumijae Karaman, 1972 (10, Figs), type locality Montenegro, Runija Mountain. Synonym of $P$. affinis komareki by lowering the latter to a subspecific status.

Poecilimon affinis komareki; Heller, 1984 (82). 


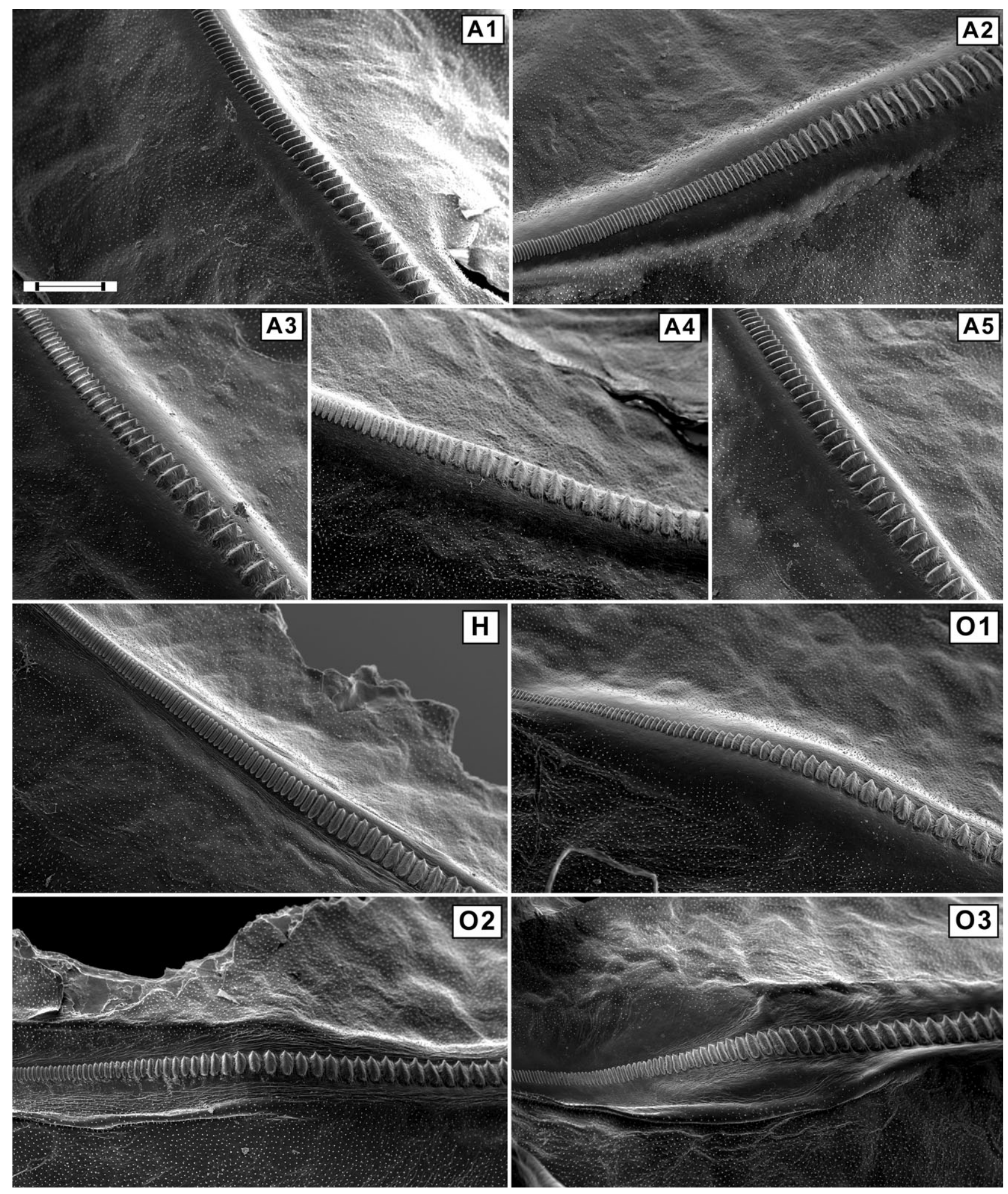

Fig. 5. SEM-photographs of the middle part of the stridulatory files of P. affinis (A1-A5), P. hoelzeli (H) and P. ornatus (O1-O3) (symbols and corresponding material as in Fig. 4). Scale $=200 \mu \mathrm{m}$.

Variation (general appearance - Fig. 1B). Similar to $P$. ornatus and the other widely distributed species in this group in terms of the variation in body size, width of fastigium in relation to scapus, upcurving of pronotum and colouration. This is generally connected with altitude (see above; Discussion). Sometimes, however, both small and large animals were observed together (e.g. at $1950 \mathrm{~m}$ in
Rila Mountains), which is one reason for assuming these as different taxa (e.g. Pavićević \& Karaman, 2001). The pronotal shape is also quite variable and cannot be used as a distinctive feature within the group. The incurvation of cerci (Fig. 3A1-A14) is stronger than in P. ornatus, with the apical parts almost at right angles to the longitudinal body axis. However, at some places, especially in 
A1

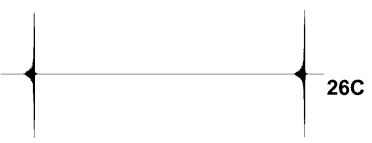

A2

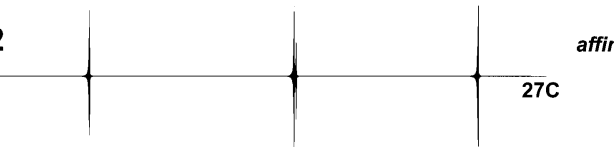

A3

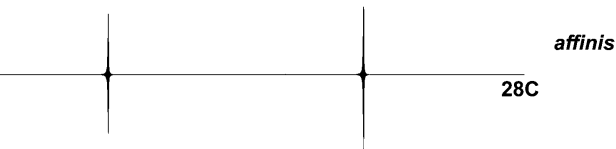

A4
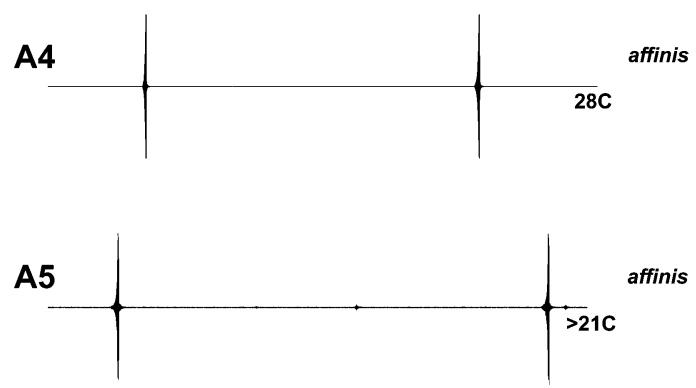

A6
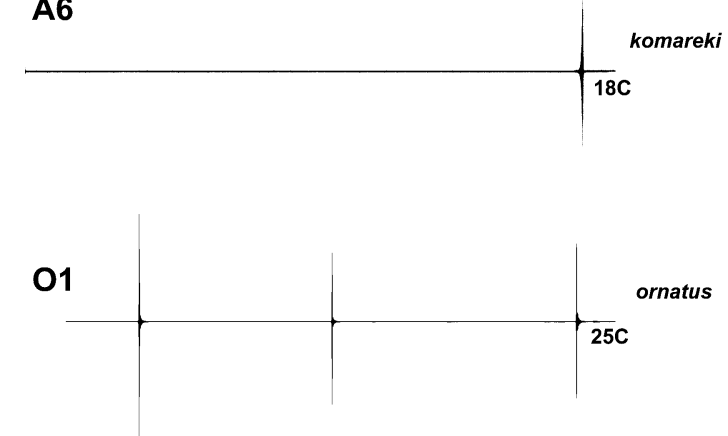

02

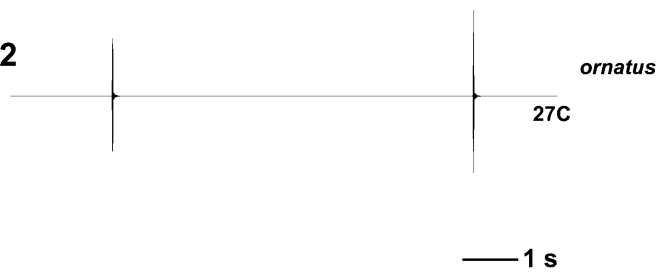

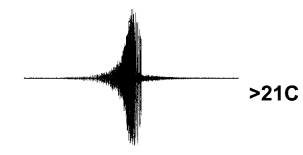
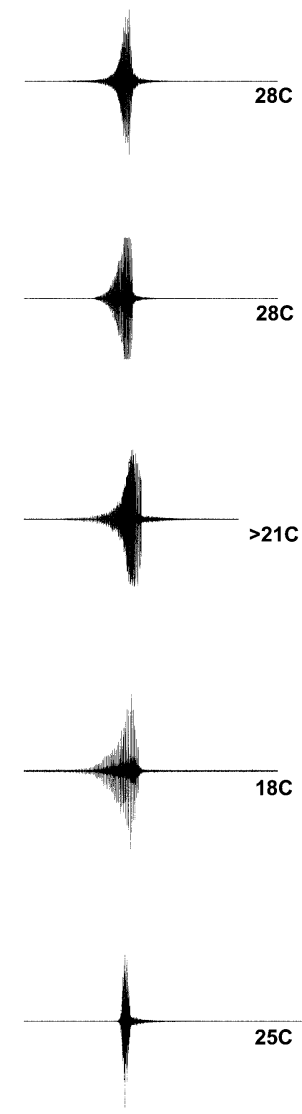

affinis

affinis

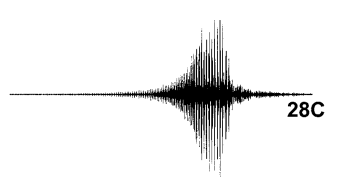

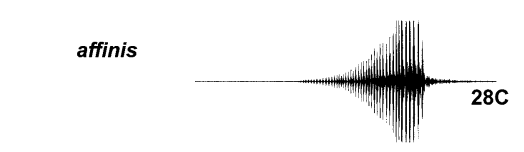

affinis

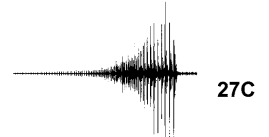

$27 \mathrm{C}$

c

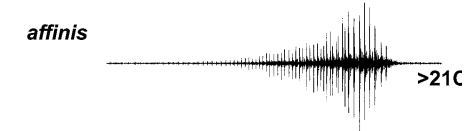

komareki

ornatus

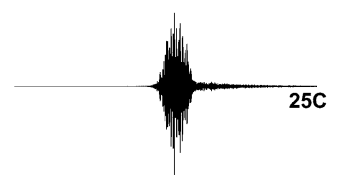

ornatus

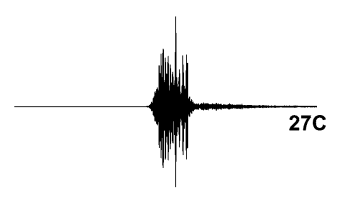

$-20 \mathrm{~ms}$

Fig. 6. Oscillograms of the song of $P$. affinis affinis (A1-A5), P. affinis komareki (A6) and P. ornatus (O1, O2) recorded at three different speeds: A1 - P. affinis, Bulgaria, Ruy Mt. foothills, road between Trun and Lomnitsa vill., 750 m, 16.vi.2007, Chobanov \& Ilieva leg. (CC), rec. 2007P186; A2 - P. affinis, Bulgaria, Rila Mts, above Rilski Manastir Monastery, 2000-2400 m, 17.viii.2008, Chobanov \& Ilieva leg. (CC), rec. 2008P203; A3 - P. affinis, Bulgaria, Pirin Mts, Shiligarnika place, 1800-2000 m, 27.-28.vii.2009, Chobanov leg. (CC), rec. 2009P063 (unspecified male); A4 - P. affinis, data as in A3, rec. 2009P080 (male No. 5); A5 - P. affinis, Ukraine, Cherkaska Oblast, Kanev Forest Reserve (4944N, 31³0’E), 18.-23.vi.1996, Heller leg., rec. POAF9604 (CH3308); A6 P. affinis komareki, Montenegro, Lovcen Pass $\left(42^{\circ} 25^{\prime} \mathrm{N}, 18^{\circ} 47^{\prime} \mathrm{E}\right), 800 \mathrm{~m}$, 26.vii.1982, Heller leg., rec. POAF8206; O1 - P. ornatus, Bulgaria, Alibotoush Mt., Livade place, 1700 m, 9.viii.2006, Chobanov leg. (CC), rec. 2006P306; O2 - P. ornatus, Bulgaria, Maleshevska Planina Mts, above Gorna Breznitsa vill., 800 m, 6.vii.2006, Chobanov leg. (CC), rec. 2006 P292.

the North Pirin Mountains, where P. affinis and $P$. ornatus occur parapatrically, the cercal shape of both species is more similar (compare Fig. 3A12 with Fig.
2O1-O10). Still, in some animals the shape of cercus deviates markedly from the normal range of variation 


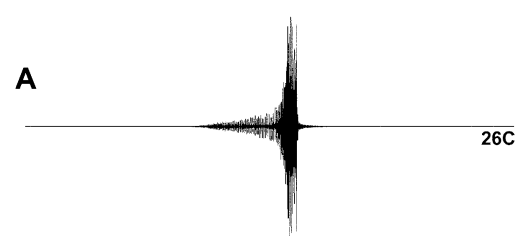

B
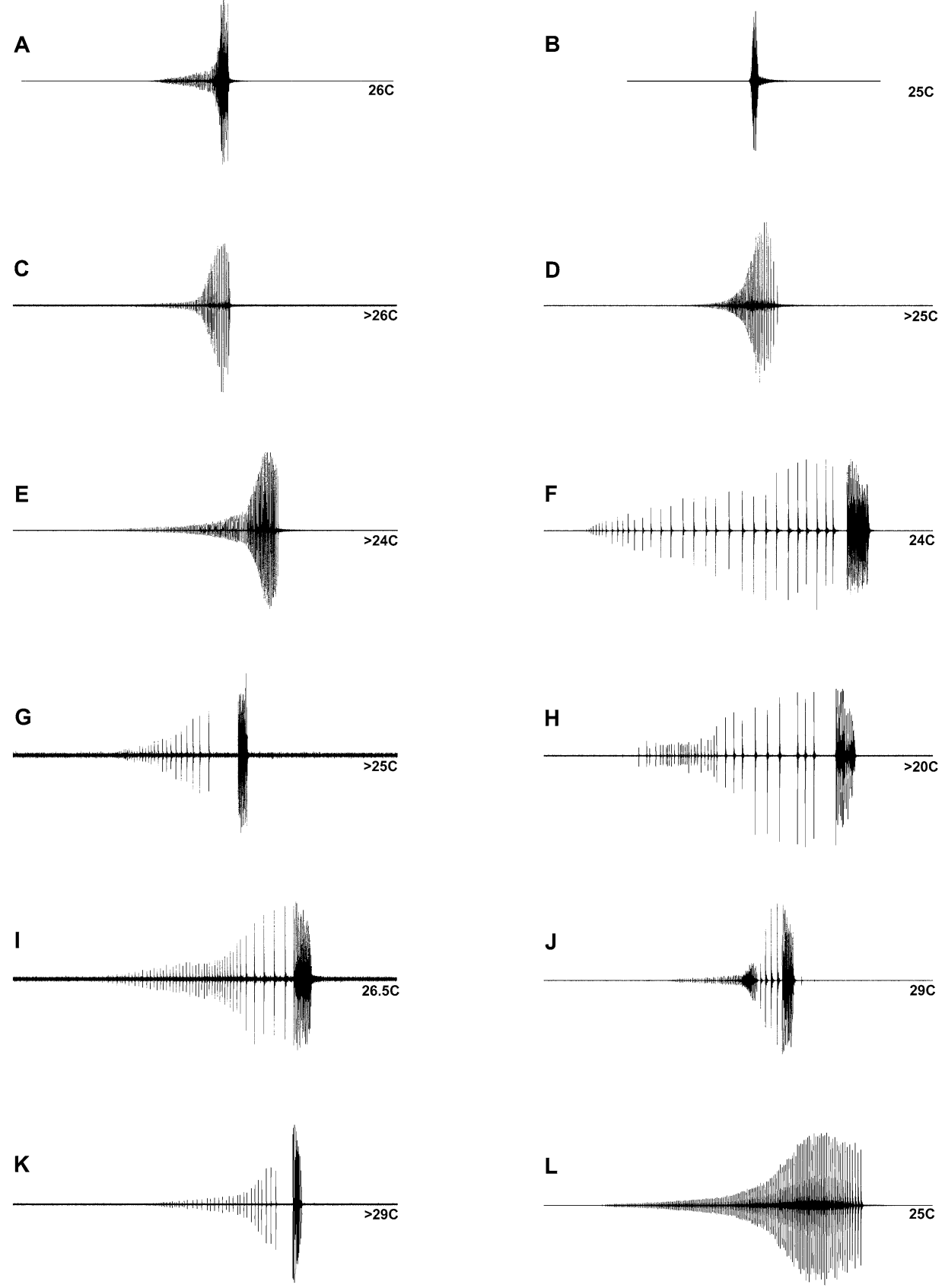

Fig. 7. Oscillograms of the song: A - P. affinis, Bulgaria, Ruy Mt. foothills, road between Trun and Lomnitsa vill., $750 \mathrm{~m}$, 16.vi.2007, Chobanov \& Ilieva leg. (CC), rec. 2007P186; B - P. ornatus, Bulgaria, Alibotoush Mt., Livade place, $1700 \mathrm{~m}$,

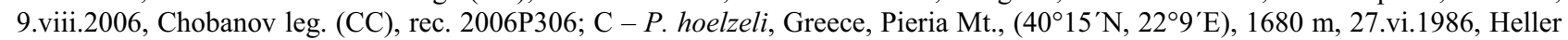
leg., rec. POHO8206 (CH0157); D - P. pindos, Greece, Mavrovouni Mt. (3951'N, $\left.21^{\circ} 7^{\prime} \mathrm{E}\right), 2$ 25.viii.1988, Heller leg., rec. POPI8809

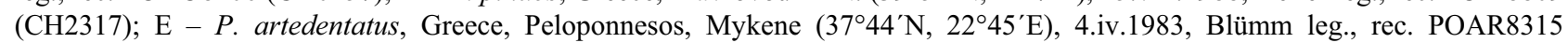
(CH1175); F - P. obesus, Greece, Amfilohia (38 $\left.51^{\prime} \mathrm{N}, 21^{\circ} 10^{\prime} \mathrm{E}\right)$, 10.vi.1980, Heller leg., rec. POOB8020 (CH1151); G - P. nobilis, Greece, Peloponnesos, Taigetos, (36 $\left.57^{\prime} \mathrm{N}, 2^{\circ} 22^{\prime} \mathrm{E}\right), 1020$ m, 15.vi.1980, Heller \& Volleth leg., rec. PONO8018 (CH1176); H - P.

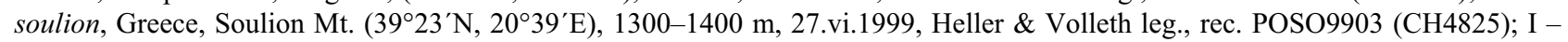
P. soulion, Greece, Timfristos $\left(38^{\circ} 54^{\prime} \mathrm{N}, 2^{\circ} 1^{\circ} 4^{\prime} \mathrm{E}\right), 1 .-30 . v i .1989$, Heller leg., rec. POOB8901 (CH2475); J - P. gracilioides, Greece, Tsoumerka $\left(39^{\circ} 24^{\prime} \mathrm{N}, 21^{\circ} 9^{\prime} \mathrm{E}\right), 1850 \mathrm{~m}, 6 .-7 . v i i i .2003$, K.-G. Heller, M. Heller \& M. Volleth leg., rec. POGC0302 (CH6291); K - P. gracilis, Austria, Kärnten (46² $\left.7^{\prime} \mathrm{N}, 1^{\circ} 23^{\prime} \mathrm{E}\right)$, 20.viii.1989, Heller leg., rec. POGR8905 (CH2555); L - P. jablanicensis, locality and date as in description, rec. 2006P332 (male No. 2).

(Fig. 3A15), as similarly recorded for the stridulatory row by Willemse (1985).
The distinctive features are again in the shape of the stridulatory file (Heller, 1984; Willemse, 1985) (Figs 4 and 5: A1-A5) and the song (Heller, 1984) (Figs 

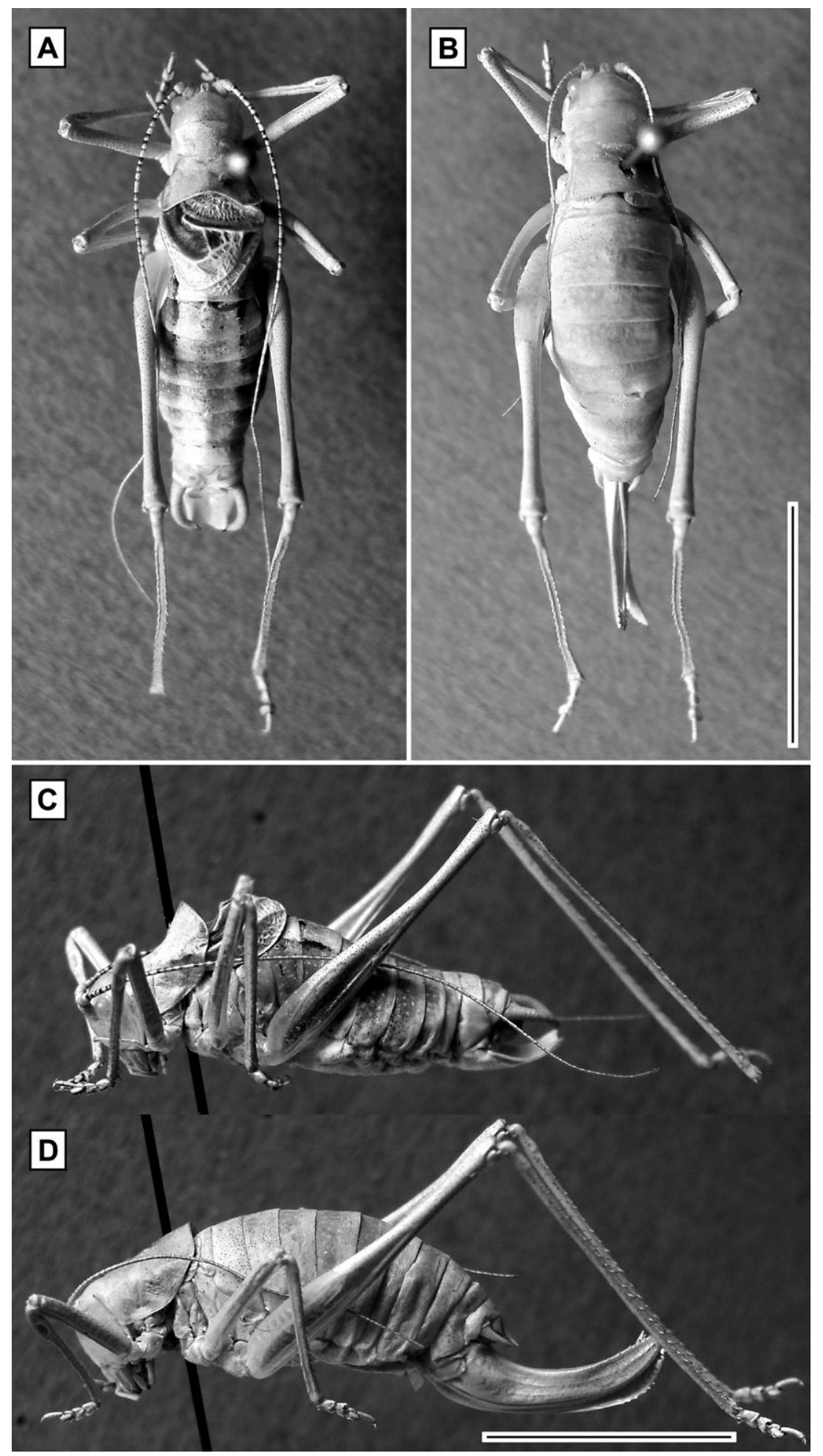

Fig. 8. Poecilimon jablanicensis: A - male (holotype), dorsal view; B - female (paratype), dorsal view; C - male (holotype), lateral view; D - female (paratype), lateral view. Scale $=1 \mathrm{~cm}$.

6A1-A6, 7A). The stridulatory file is bearing a high number of teeth (usually more than 200) and has a small bulge at the middle. However, though Heller (1988) reports 220-230 teeth in this species we observed $180-240$ teeth and the number is generally more variable in the southeastern populations ( $\mathrm{SW}$ Bulgaria). The lowest number of teeth is found in small specimens from high altitudes. Thus, the number of teeth is not a good character for distinguishing $P$. affinis from $P$. ornatus but the shape of the stridulatory file is a more reliable morphological feature for separating these species. The song also distinguishes $P$. affinis from $P$. ornatus (Fig. 6: compare A1-A6 with O1, O2; Fig. 7: compare A with B), the former produces long syllables $(100-500 \mathrm{~ms})$ with a 

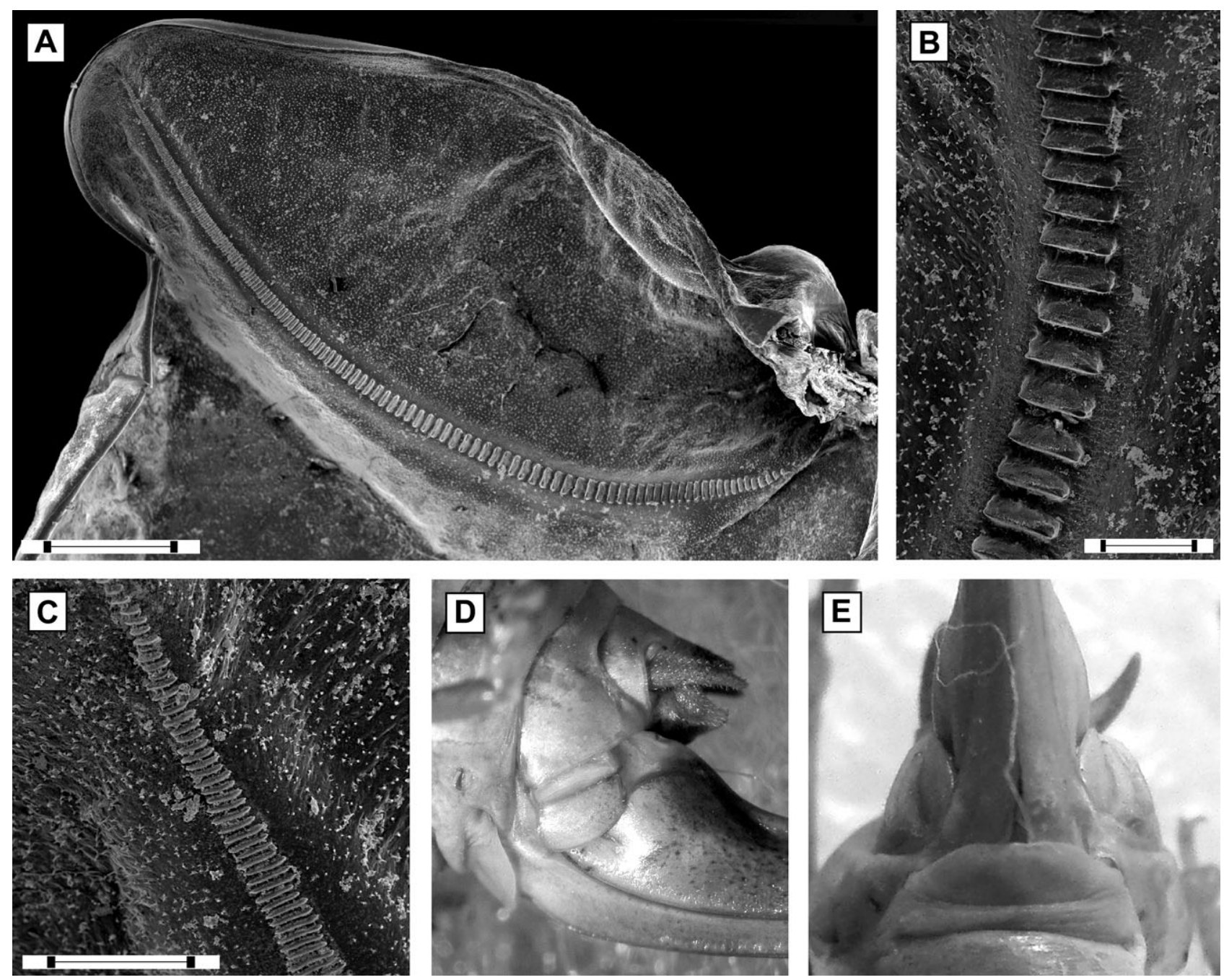

Fig. 9. Poecilimon jablanicensis: A - male stridulatory file $($ scale $=500 \mu \mathrm{m}) ; \mathrm{B}-$ middle part of male stridulatory file $($ scale $=100$ $\mu \mathrm{m}) ; \mathrm{C}$ - apical part of male stridulatory file $($ scale $=100 \mu \mathrm{m}) ; \mathrm{D}$ - base of the ovipositor in lateral view; $\mathrm{C}-$ same in ventral view.

gentle and continuous increase in amplitude at the beginning and a following high-amplitude section of 30-40 ms.

Synonymy. The study of the rich material (including types) of the Poecilimon ornatus group indicated that the populations from the mountain regions of Western and Northeastern Macedonia and Middle and central part of Western Bulgaria (see Distribution; Figs 10-11) show the same variation in morphology as Poecilimon affinis affinis (see for example Fig. 3A1-A13, Figs 4 and 5: A1-A5). The sound recordings are also similar. The song (Figs 6A1-A6, 7A) consists of single syllables, each syllable having a long, low-amplitude beginning, followed without interruption by a steep increase in amplitude to the second high-amplitude part. Again the fading of the final low-amplitude part is a result of echoes (see P. orna$t u s)$. At a temperature of $26-28^{\circ} \mathrm{C}$ the syllables of the songs of individuals from these populations usually last $150-200 \mathrm{~ms}$ with a high-amplitude part of $30-40 \mathrm{~ms}$. The song duration tends to decrease east- and southwards, being shortest in populations from the northern slopes of the Pirin Mountans in Bulgaria, which border the populations of $P$. ornatus. Whether this is a result of geneflow is still a matter of speculation. The song of one individual, which did not differ in morphology, was aberrant with a shorter low-amplitude part of the syllable (Fig. 6A4) and syllables hardly longer than $100 \mathrm{~ms}$.

These results indicate the synonymy of $P$. mistshenkoi mistshenkoi, $P$. affinis ruenensis, $P$. affinis rilensis, $P$. affinis medimontanus and $P$. harzi with $P$. affinis affinis (P. affinis s. str. sensu Heller, 1984).

Recently, Pavićević \& Karaman (2001) again raised $P$. poecilus to species level, pointing out that it is “... a good species, which can be supported by our supposition that it was found together with $P$. affinis serbicus on the same bush of Juniperus on Prokletije Mts". This was not confirmed by a diagnostic comparison of morphological, bioacoustic or other characters. Heller (1984) noted the tendency for body size to decrease (the small body size and pronotum shape being characteristics of $P$. poecilus by Ramme, 1951) with increasing altitude in the populations of $P$. affinis on the western slopes of Shar Mountains (locus typicus of P. poecilus). Karaman (1974) discusses the general tendency for the pronotal metazona to be raised and black colouration to predominate where this species is abundant and in populations of $P$. affinis from high altitudes (with increased humidity). Indeed, 


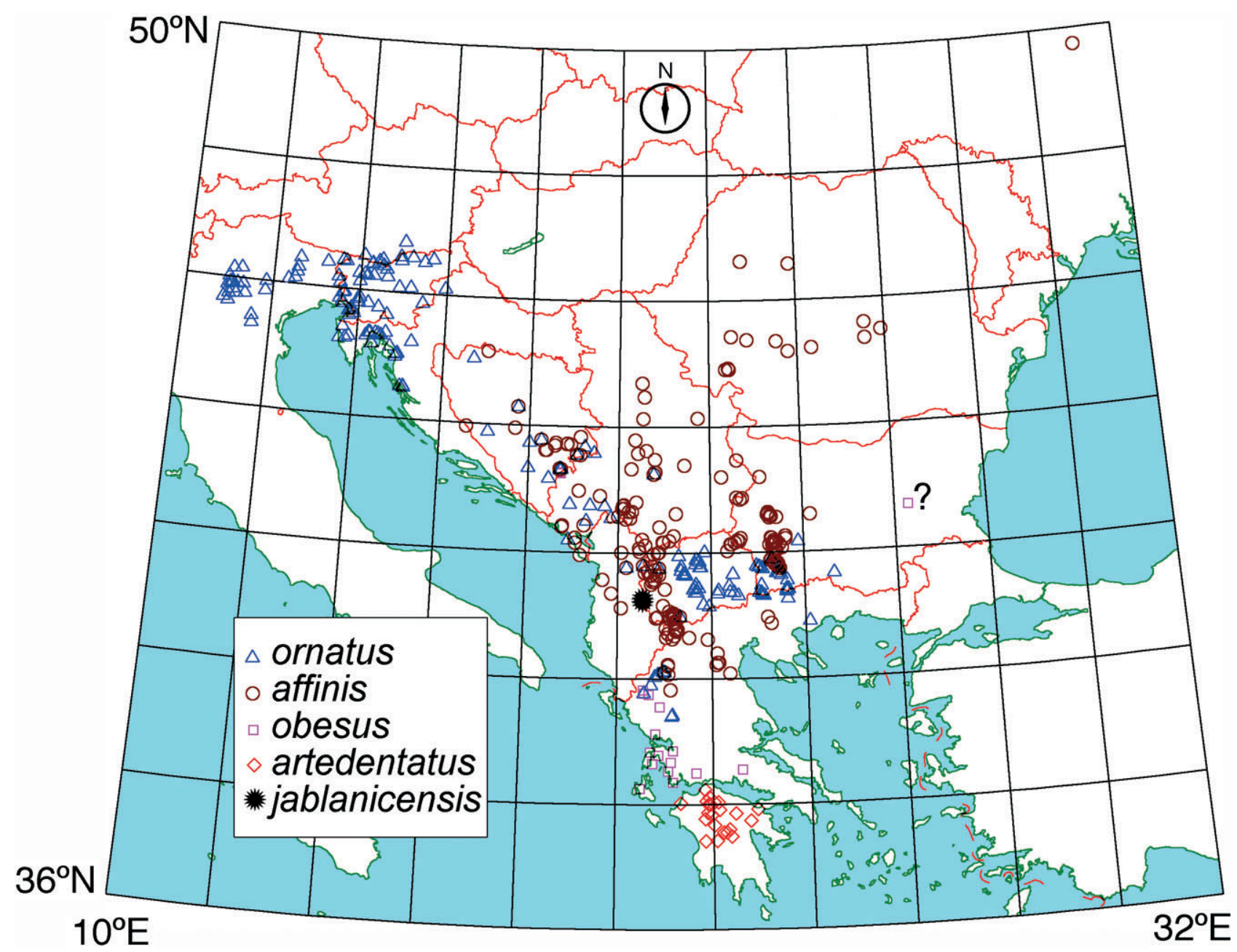

Fig. 10. Distribution of P. ornatus, $P$. affinis, P. obesus, P. artedentatus and P. jablanicensis.

small melanistic individuals occur at the upper altitudes of the distributions of both $P$. affinis (above $2000 \mathrm{~m}$ in the Shar Mountains in Macedonia and Rila and Pirin Mountains in Bulgaria) and P. ornatus (e.g., above $2000 \mathrm{~m}$ in the Jakupica Mountains in Macedonia), while large greenish $P$. affinis with a weakly raised pronotum were observed at $900 \mathrm{~m}$ in the valley of the Radika River (Macedonia). This tends to support Heller's (1984) suggestion that $P$. poecilus and $P$. affinis are synonymous. Karaman (1972) described Poecilimon komareki rumijae on the basis of already mentioned generally variable morphological characters like the shape of the pronotum and body size. Because of the lowering $P$. komareki to a subspecies of $P$. affinis by Heller (1984), the weakly differing $P$. komareki rumijae, considered by Eades \& Otte (OSF online, 2009) as a subspecies of $P$. affinis, becomes an infra-subspecific category. Thus (see also Heller, 1984), it is here considered synonymous with $P$. affinis komareki ( $=$ P. komareki rumijae, syn.). Karaman (1974) describes a further two subspecies of $P$. affinis $-P$. affinis serbicus and $P$. affinis hajlensis, which are distinguished by subtle differences in the shape of the pronotum and cerci, and body dimensions. In addition, the shape of the stridulatory file of individuals in some populations in Serbia differs from that typical for $P$. affinis (Willemse,
1985). The shape of the cerci of one specimen from Durmitor (Montenegro) differed from that of individuals in all other populations of $P$. affinis investigated (Fig. 3A15). However, its taxonomic position will remain speculative until the songs of individuals from these populations are recorded.

Distribution (Figs 10, 11, Appendix). The main part of this species' range covers the Balkan Peninsula (Western and Central Bulgaria, Northwestern Greece, Western Macedonia, Albania, Serbia, Montenegro, Bosnia and Hercegovina), reaching also Romania and, in an isolated spot, the Kanev region in Southern Ukraine. P. affinis occurs throughout the Southwestern Carpathians (Romania) and the Western Stara Planina (Bulgaria) and the mountains in Southeastern Serbia and the central part of Western Bulgaria, where the distribution divides into two arms - western and eastern, which encompass the southern population of $P$. ornatus. The western, more extensive, arm runs through the Kosovo Highlands into the Pindo-Dinaric mountain group north to Bosnia and Hercegovina, and south to the North Pindos (Greece), and in the west reaching the Pelagonian horst anticline on the Baba (Pelister) Mountain (Macedonia). The eastern arm, encompassing the population of $P$. ornatus from the North, extends into the Rhodopean mountain group 


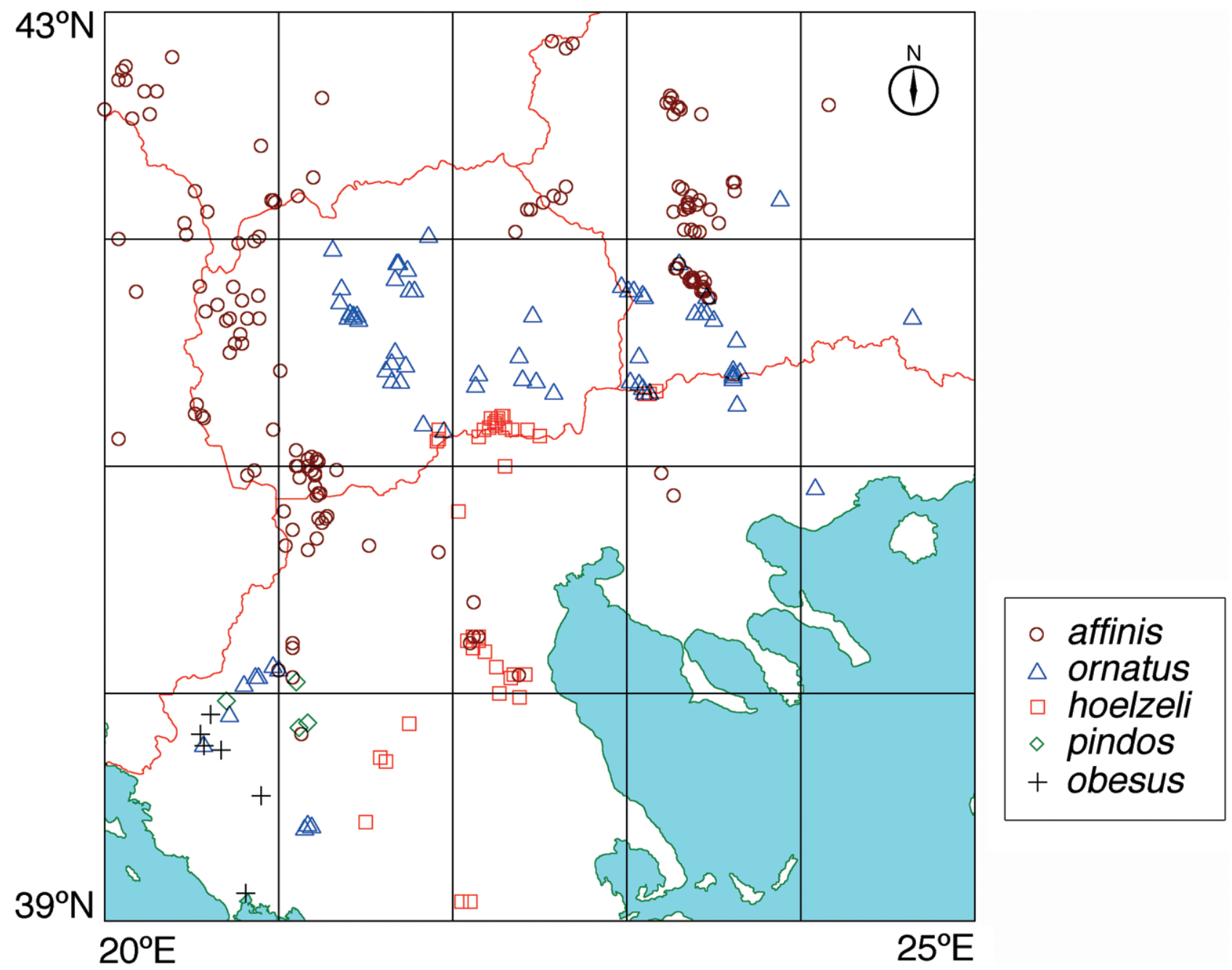

Fig. 11. Distribution of P. affinis, P. ornatus, P. hoelzeli, P. pindos and P. obesus on the Central Balkan Peninsula.

reaching Rila and North Pirin Mountains (Bulgaria) in the east. Isolated localities are recorded for the Lakhanas and Vertiskos Mountains (Greece: Makedhonia).

Along the borders between the ranges of $P$. ornatus and $P$. affinis these species are not recorded as occurring sympatrically. However, there seems to be a narrow, southeast-northwest oriented contact zone between populations of these species in the Northern Pirin Mountains, where they may occur both sympatrically and even syntopically. Moreover, Köhler (1988) reports both species from the same area. Other possible areas of contact are the Treska River Valley in Macedonia and some places in Greece.

\section{Poecilimon hoelzeli Harz, 1966}

Poecilimon ornatus hoelzeli Harz, 1966 (23, Figs 10-14), type locality Macedonia, Kožuf Mt., Mala Rupa, 1200 m; Harz, 1969 (120, Fig. 349). Subspecies of P. affinis after Heller, 1984.

Poecilimon hoelzeli; Willemse, 1982 (158, 160, Figs 11-14, 128-130, 184-186, 201, 202); Heller, 1988 (49, Figs 34-F, 35-E, 88).

Poecilimon affinis hoelzeli; Heller, 1984 (82-83, Figs 6, 8-B).
Poecilimon kisi Peshev, 1980 (36-37), type locality Bulgaria, Belassitsa Mt., northeastern slope of Kalabak Peak, Demirkapiya Locality, 1700-1900 m, syn. n.

Variation (general appearance - Fig. 1C). This species usually inhabits mountains and exhibits little morphological variation. However, at some places at altitudes between $600-700 \mathrm{~m}$ quite large animals with a less elevated pronotal metazona and little melanistic colour are recorded (e.g. Kozhuf Mountain, Macedonia). Thus, generally its variation falls within that of $P$. ornatus and $P$. affinis (see Discussion). The incurvation of the cerci (Fig. $3 \mathrm{H})$ is marked and typical of this species. The stridulatory file (Figs 4 and 5: H) and song (Fig. 7C; Heller, 1984) differ slightly from those of $P$. affinis and are more uniform. The number of stridulatory teeth is high and ranges between 235 and 270 .

Synonymy. This species is closely related to $P$. pindos and $P$. affinis although initially described as a subspecies of $P$. ornatus. Its specific features include the shape of male cerci, pronotum and tegmina, the shape of the stridulatory row and number of stridulatory teeth. A unique characteristic of $P$. hoelzeli is the basal fold on dorsal margin of the lower ovipositor valve, which bears a highly visible knob-shaped process. A new distinctive 


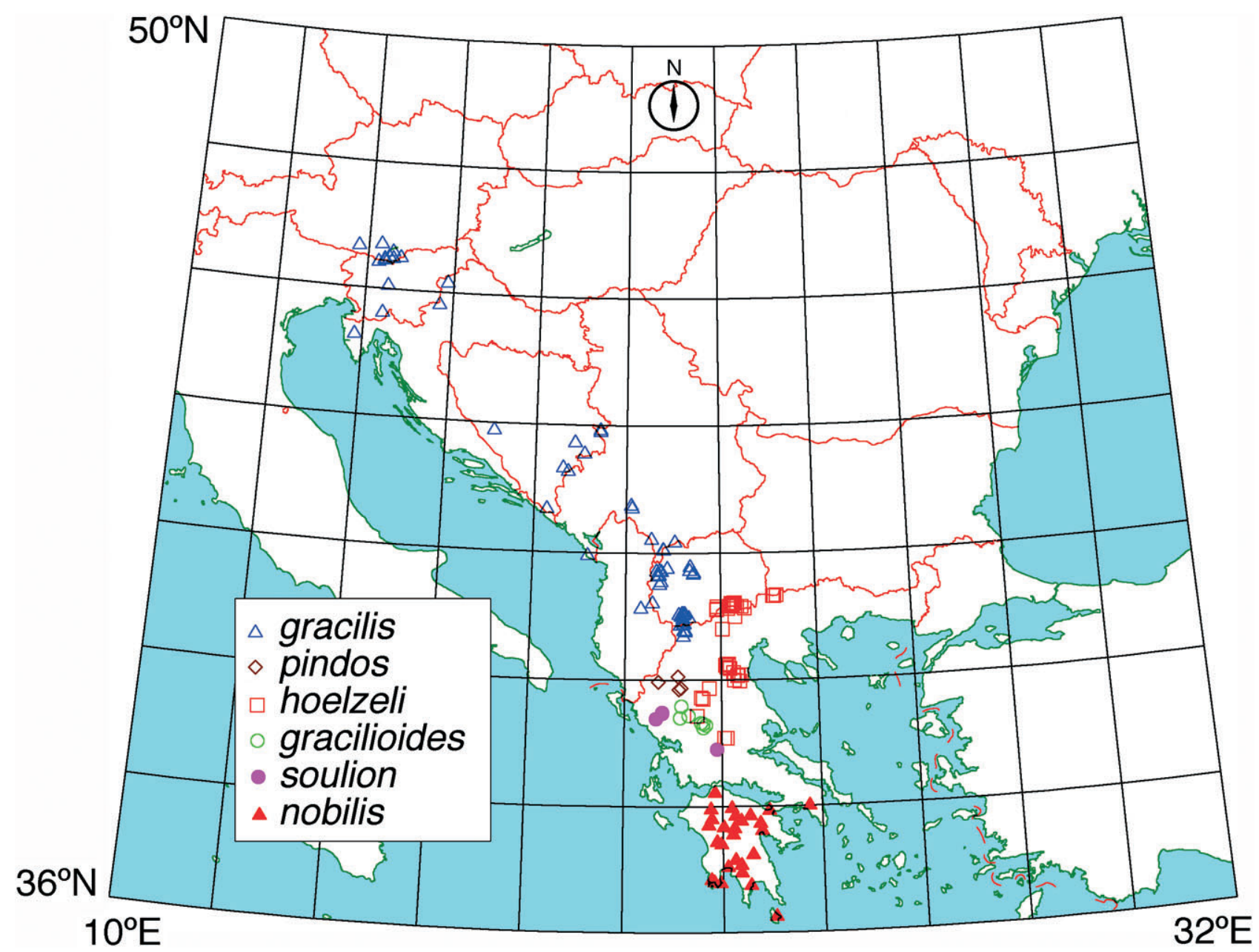

Fig. 12. Distribution of $P$. gracilis, $P$. pindos, $P$. hoelzeli, $P$. gracilioides, $P$. soulion and $P$. nobilis.

feature is the number of stridulatory teeth, which is generally higher than in its relatives (usually more than 240). The specific status of $P$. hoelzeli was confirmed both by the stability of its distinctive characters (see Willemse, 1982; Heller, 1988), its syntopic occurrence with $P$. ornatus on the Belassitsa Mountain (SW Bulgaria) and para- and sympatric occurrence with $P$. affinis (Willemse, 1985 ) in Greece (Pieria Mt., $1500 \mathrm{~m}$ ) (Willemse, 1982 as $P$. ornatus). The results of the study of the type material and newly collected specimens of $P$. kisi from Belassitsa Mt. (Bulgaria) clearly support its synonymy with $P$. hoelzeli.

Distribution (Figs 11, 12, Appendix). The range of this species is restricted to a small area in the Central Balkans, covering Southeastern Macedonia, extreme Southwestern Bulgaria and the central part of Northern Greece southwest to Pieria Mt.

\section{Poecilimon gracilis (Fieber, 1853)}

Barbitistes gracilis Fieber, 1853 (261), type locality "Illyrien". Isophya tölgi Ebner, 1908 (332), type locality Bosnia and Hercegovina, Cajniza (Ramme, 1933). Synonym of P. gracilis after Ramme (1933).

Poecilimon gracilis; Ramme, 1933 (515, Pl. 6, Fig. 5, Pl. 8, Fig. 6, Pl. 11, Fig. 5); Bey-Bienko, 1954 (277); Harz, 1969 (123, Figs 280, 324, 363-365); Willemse, 1982 (158, 160, Figs 11-14, 128-130, 184-186, 201, 202); Heller, 1984 (85, Figs 8-C, 9-C, 10-E); Heller, 1988 (51-52, Figs 36B, 88, 121C).
Poecilimon mavrovi Karaman, 1958 (38-39, Figs 8-12), type locality Macedonia, Bistra Mt., Careva Cheshma and Verbenska Gora. Synonym of $P$. gracilis after Heller (1984). Poecilimon mavrovi; Harz, 1969 (123-124).

Variation (general appearance - Fig. 1D, frequency spectrum - Fig. 15). This species is morphologically variable within its wide range (Willemse, 1982) in terms of body size and shape of the pronotum and cercus (Fig. $2 \mathrm{G}, \mathrm{C}$ ) etc. The differences are of a similar scale to the differences in these characteristics in $P$. ornatus and $P$. affinis, though it is difficult to connect them to microclimate or other factors. The song (Fig. 7K; Heller, 1984), however, is typical and clearly specific to this species.

Distribution (Figs 12, 13, Appendix). S Austria, Slovenia, Croatia, Bosnia and Hercegovina, Serbia, Montenegro, Albania, Macedonia, Northeastern Greece (Florina).

\section{Poecilimon jablanicensis, sp. $\mathbf{n}$.}

Diagnosis. Poecilimon jablanicensis, sp. n., is readily defined by the shape of its pronotum, tegmina, cerci (Figs $1 \mathrm{E}, 2 \mathrm{~J}, 8,9$ ) and song (Figs 7L, 14A) of the male, by the reduced, non-overlapping tegmina in the female (see Fig. $8 \mathrm{~B}, \mathrm{D})$ and the reduced size of the auditory spiracle in both sexes (see Fig. 8C, D). 


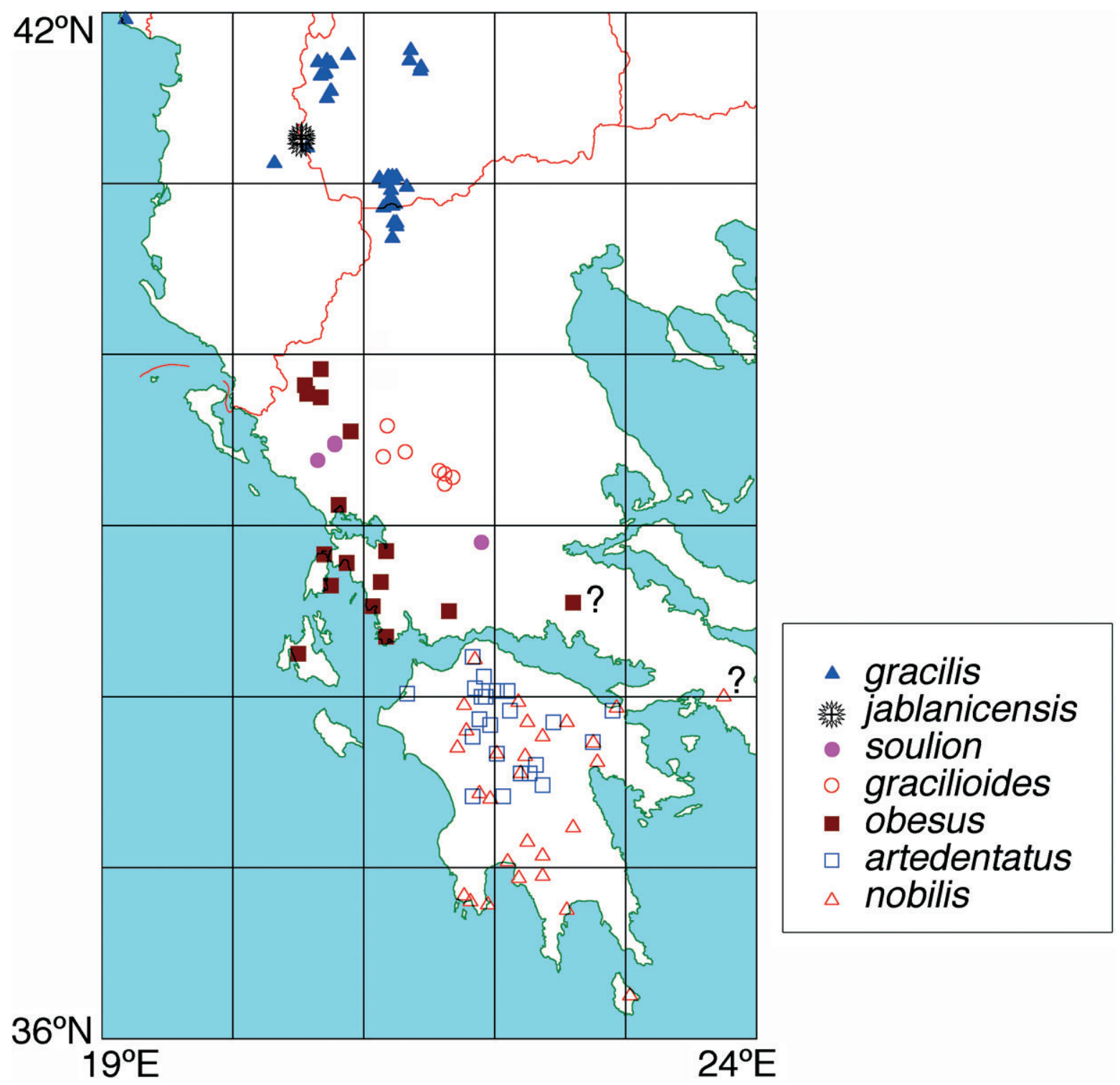

Fig. 13. Distribution of $P$. gracilis, $P$. jablanicensis, $P$. soulion, $P$. gracilioides, $P$. obesus, $P$. artedentatus and $P$. nobilis in the Central and Southern Balkans.

This species is one of the slender species of the Poecilimon ornatus group. It is most closely related to $P$. gracilis and $P$. gracilioides, the first being probably the ancestral taxon that gave rise to this specialized mountain form, which inhabits only open (pseudo-) subalpine areas. The unique morphological autapomorphies of $P$. jablanicensis are the reduced size of the auditory spiracle in both the male and female, and the rudimentary tegmina in the female, which do not overlap. Other characters differentiating this new species from $P$. gracilioides are the wider and strongly upcurved metazona of the pronotum, bigger and strongly bulging male tegmina, clearly longer stridulatory file with a greater number of teeth, smaller body size, shape of cerci, and length of subgenital plate. In addition, on the stridulatory file (Fig. 9A-C) of this new species the teeth gradually change in size, while in $P$. gracilioides (and $P$. soulion) there is an abrupt change in the size of the teeth. The colouration of $P$. jablanicensis resembles that of $P$. gracilis, but the integument is much duller and the general colour has usually more yellowish green than fresh-green (compare Fig. 1: D with E).

The song of Poecilimon jablanicensis differs greatly from the two- to three-partitioned and shorter song of its closest relatives, $P$. gracilis and $P$. gracilioides. The few recordings of the song of $P$. gracilioides indicate that the syllables are produced at much longer intervals. Generally the song resembles that of the sympatric $P$. affinis (compare Fig. 6A1-A6 with Figs 7L, 14A). In P. jablanicensis the syllables are regularly repeated over a long period, while in $P$. affinis they are normally separated by long intervals, irregularly repeated or sometimes a few syllables are produced with short intervals. The syllable has a similar shape in both taxa, but in $P$. jablanicensis it is much longer $\left(750-350 \mathrm{~ms}\right.$ at $26-30^{\circ} \mathrm{C}$, probably up to more than $1 \mathrm{~s}$ at lower temperatures) than in $P$. affinis $\left(500-100 \mathrm{~ms}\right.$ at $\left.18-30^{\circ} \mathrm{C}\right)$. In $P$. jablanicensis the highest amplitude-part $(\sim 100-150 \mathrm{~ms})$ is about $3-5$ times longer than in $P$. affinis $(30-40 \mathrm{~ms})$ and includes a greater 
number of impulses. The song of $P$. jablanicensis resembles that of $P$. artedentatus (Fig. 7E; Heller, 1984), which is endemic in the Peloponnesos in Southern Greece, and even more so by having a smaller number of impulses. The frequency spectrum of $P$. jablanicensis covers lower frequencies than that of its relatives, with a maximum at about $22 \mathrm{kHz}$ (but see below) compared to the $30 \mathrm{kHz}$ in P. gracilis (Heller, 1988; see Fig. 15).

\section{Description}

Male (Figs 1E, 8A, C). Medium sized and considerably slender. Integument moderately shiny to dull (especially that of the pronotum).

Head: fastigium of vertex extended anteriorly, lateral margins parallel, length and width about equal to those of second antennal segment, width about half to two-thirds of that of scapus, with strong longitudinal groove. Antennae with second segment conspicuously swollen, about one-third wider than the third segment.

Thorax: pronotum saddle shaped both in dorsal and lateral view; prozona slightly raised anteriorly, metazona dome-raised and very broad above tegmina, transverse sulcus cutting the median line of pronotum before its middle at the start of its backward extension. Posterior margin is concave to barely emarginated. Lower margin of pronotal lateral lobe slightly wavy, its hind margin rounded. Auditory spiracle small for this species-group, much smaller than in its relatives, $P$. gracilis and $P$. gracilioides; its vertical diameter smaller than the diameter of one eye (similar to that in the females of the latter two species; see Fig. 1 in Stumpner \& Heller, 1992), aperture narrow elliptical, only slightly covered by the pronotal lateral lobe. Tegmina conspicuously large, wider than pronotum, anal margin protruding at the lateral edge of pronotum with the tip of the stridulatory vein forming an acutely-rounded lobe. Apical margin of tegmina reaches from the middle of second to the beginning of third abdominal tergite. Visible length of tegmina is equal to or slightly shorter than that of pronotum, complete length greater than that of pronotum. Texture of tegmina is rough, not mostly membranous as in $P$. gracilis. Stridulatory vein $(\mathrm{CuP})$ is strong. The medio-cubital area is dome-raised. Medial field forms large, thick, membranous resonator. Stridulatory file of left tegmen (Fig. 9A-C) about 3.3 (178 teeth) $-3.4 \mathrm{~mm}$ long, bearing $175-210$ teeth $(6$ males, mean $\pm \mathrm{SD}=193 \pm 12$, median $=$ 194; the basal part of file frequently bears $2-6$ narrower, sometimes spine-like and somewhat isolated teeth, which also were counted), almost reaching the edge of the tegmen at the apical part of the file. Fore femur longer than pronotum. Hind femora lack ventral spines.

Abdomen: margins of tergites straight or weakly excised, especially the first tergite. Long stout cerci (Fig. 2J) slightly and evenly curved inwards and downwards after the middle; basally strongly dorso-ventrally thicker. Apical part of cerci slightly flattened dorso-ventrally, in lateral view slightly S-shaped (Fig. 8C) and tapering to the tip, in dorsal view almost equally thick along whole length. Cercus tip shortly tapering to a wide end, bearing a large tooth. Cercus tooth long, wide, with an inner crest

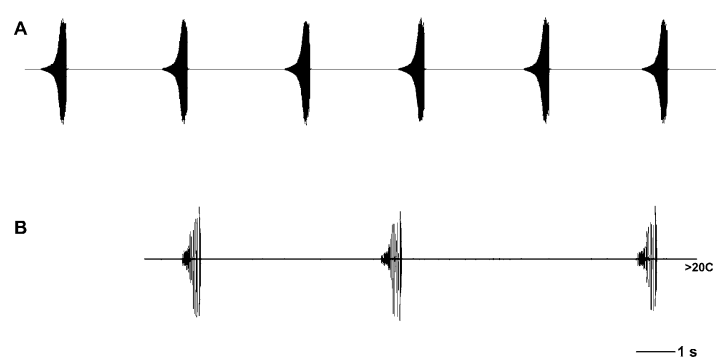

Fig. 14. Oscillograms of the male calling songs of $P$. jablanicensis, rec. 2006P332 (A) and P. soulion, rec. POSO9903 (B) (data as in Fig. 7).

bordering an inner ventrolateral groove. Epiproct large, slightly broader than long, with an ovally obtuse hind margin. Subgenital plate (see Fig. 8A, C) long, reaching tip of cerci, wide, lateral margins almost parallel, only slightly converging posteriorly, posterolateral edges triangularly protruding, posterior margin with slightly wavy excision.

Colouration (see Fig. 1E): light green to yellowishgreen. Vertex, pronotum, tergites and legs finely speckled rusty brown. Antennae yellowish with black rings. Head and pronotal dorsum with two lateral thin pale yellowish stripes, which on metazona of pronotum broaden posteriorly and meet at the hind margin; there is a similar pale yellow median sripe along the vertex. Dorsolateral corners of pronotum on metazona with red triangular stripes, on the outside border of the yellow stripes. Sometimes rusty-red spots or stripes are present on fastigium of vertex, vertex, legs, etc. Tegmina yellowish with mediocubital area brown. Tibiae yellowish-green to yellowish-brown. Abdomen of the same general colouration with two broad pale yellowish dorsal stripes, sometimes laterally bordered with black spots starting from the base of terga but not reaching their posterior margins. Sometimes, shorter and smaller black spots medially border the stripes. Cercus yellowish, tooth black.

Female (Figs 8B, D, 9D, E). Integument dull. Pronotum almost cylindrical and straight dorsally with the transverse sulcus cutting the median line after the middle of pronotum. Hind margin of pronotum slightly concave to slightly convex. Metazona weakly widened. Auditory spiracle very small, its diameter much smaller than the eye. Tegmina fully covered by pronotum, not overlapping each other and reaching at most to the middle of first tergite, roundly-triangular, with a transverse, almost straight apical margin. Stridulatory apparatus reduced. Cerci long, surpassing the epiproct, conical, apical fourth slightly angularly incurved. Epiproct elongated and oval. Subgenital plate (Fig. 9D, E) short, almost oval, with a barely angled tip. Ovipositor more than twice as long as pronotum, apical part with short, stout teeth dorsally, ventrally and laterally, as in allied species. Gonangulum flattened. Basal fold of dorsal margin of lower ovipositor valve (Fig. 9D) flattened, lamelliform, forming with gonangulum a small, shallow, laterally-facing groove.

Colouration: unicolourous green, weakly speckled rusty brown, lateral pale yellow stripes present on head and 
pronotum; in some specimens there are small dorsolateral pronotal red spots and dorsal abdominal pale stripes, rarely bordered with black.

Measurements $(\mathrm{mm})$. Body ô 19.0-21.2 (mean 20.2, $\mathrm{n}=7$ ), ㅇ 17.5-20.2 (mean 19.2, $\mathrm{n}=3$ ); pronotum ô 3.4-3.9 (mean $3.5, \mathrm{n}=7$ ), ㅇ 3.5-4.1 (mean 3.9, $\mathrm{n}=3$ ); male tegmen $\sim 4-4.5$, visible part $~ 3-4$; hind femur ô 11.4-14.0 (mean 13.0, $\mathrm{n}=7$ ), ㅇ 13.1-13.5 (mean 13.3, $\mathrm{n}=3$ ); male subgenital plate 3.9-4.4 (mean 4.1, $\mathrm{n}=7$ ) ovipositor 9.2-9.6 (mean 9.4, $\mathrm{n}=3$ ). Measurements were taken between the mid-lines of the structures (in the case of the pronotum and male subgenital plate this is not the longest part)

Bioacoustics. Male calling song (Figs 7L, 14A) consists of single syllables, repeated regularly for a long time without noticeable pauses, with comparatively short syllables periods. The syllables have a goblet-like shape starting with a very quiet part and gently increasing to a crescendo in the last fourth, which has the highest amplitude.The songs of two males placed in different environmental situations were studied (Table 1).

At $26^{\circ} \mathrm{C}$ (male labelled No. 2 in CC) the syllables lasted 524-747 ms (mean $634 \pm 71, \mathrm{n}=62$ ), with the syllables longer at the beginning of the song and gradually decreasing with time. The syllables consisted of 143-162 (mean $157 \pm 6, \mathrm{n}=30$ ) impulses with an impulse period of 3-10 ms (mean $4.1 \mathrm{~ms}$ ). The impulse period at the beginning and in the middle of the song is shorter (about 3-4 ms, except the first impulse, which has a period of up to $9 \mathrm{~ms}$ ) than in the last fourth of the song $(4-5 \mathrm{~ms}$, reaching up to 6-10 $\mathrm{ms}$ in the last 4-5 impulses). Typical of the shape of the syllables is the gentle increase in the amplitude over the first $\sim 100-110$ impulses, with an abrupt crescendo at impulses $110-125\left(130^{\text {th }}\right)$ and maximum amplitude achieved in the last 30 impulses.

The same specimen at $29-30^{\circ} \mathrm{C}$ produced syllables lasting 362-428 ms (mean $396 \pm 17, \mathrm{n}=54$ ), with the shortening caused by the shorter impulse period (2-6 ms, mean 2.6) while retaining the same number of impulses.

Another male (labelled No. 1 in CC) at $29-30^{\circ} \mathrm{C}$ differed slightly in having a similar syllable duration but lower number of impulses. However, at this temperature the first impulses of a syllable are quickly produced, which in combination with the low amplitude, make it difficult to distinguish single impulses. In this case an isolated impulse also frequently followed the syllables at an interval of more than $10 \mathrm{~ms}$ and up to $85 \mathrm{~ms}$.

Additional variation in the song was observed in male Nol (CC) when singing in duet with another male. In this case, the song consisted of longer syllables, separated by shorter intervals. Thus, while the syllable period is not (significantly) affected by body temperature, it could be influenced by competition for mates. In addition, the mean impulse period was longer due to the longer intervals between the last impulses in a syllable. This could be due to competition between sexually active males and hence song plays a part in the competiton for mates.

Tegmen movements were not recorded but observations indicate they consist of a simple fast opening and slow
TABLE 1. Characteristics of the male song of P. jablanicensis, sp. n., recorded from two males in different conditions and situations.

\begin{tabular}{|c|c|c|c|c|}
\hline \multirow[b]{2}{*}{$\begin{array}{l}\text { Specimen } \\
\mathrm{T}^{\circ} \mathrm{C}\end{array}$} & \multicolumn{4}{|c|}{ Character } \\
\hline & $\begin{array}{c}\text { Syllables } \\
\text { duration }(\mathrm{ms})\end{array}$ & $\begin{array}{l}\text { Syllables } \\
\text { period (s) }\end{array}$ & $\begin{array}{c}\text { Imulse period } \\
(\mathrm{ms} ; \text { mean })\end{array}$ & $\begin{array}{c}\text { Number } \\
\text { of impulses }\end{array}$ \\
\hline $\begin{array}{l}\text { Male No. } 2 \\
26^{\circ} \mathrm{C}\end{array}$ & $\begin{array}{c}634 \pm 71 \\
(524-747) \\
\text { Mode }=735 \\
\text { Median }=640 \\
n=62\end{array}$ & $\begin{array}{c}3.3 \pm 0.5 \\
(2.7-4.8) \\
\text { Mode }=\mathrm{N} / \mathrm{A} \\
\text { Median }=3.2 \\
\mathrm{n}=62\end{array}$ & 4.1 & $\begin{array}{c}157 \pm 6 \\
(143-162) \\
\text { Mode }=161 \\
\text { Median }=159 \\
\mathrm{n}=30\end{array}$ \\
\hline $\begin{array}{l}\text { Male No. } 2 \\
29-30^{\circ} \mathrm{C}\end{array}$ & $\begin{array}{c}396 \pm 17 \\
(362-428) \\
\text { Mode }=411 \\
\text { Median }=394 \\
\mathrm{n}=54\end{array}$ & $\begin{array}{c}3.0 \pm 0.9 \\
(1.1-5.8) \\
\text { Mode }=3.0 \\
\text { Median }=2.8 \\
\mathrm{n}=62\end{array}$ & 2.6 & $\sim 150-160$ \\
\hline $\begin{array}{l}\text { Male No. } 1 \\
29-30^{\circ} \mathrm{C} \\
\text { calling }\end{array}$ & $\begin{array}{c}408 \pm 39 \\
(351-475) \\
\text { Mode }=373 \\
\text { Median }=401 \\
n=50\end{array}$ & $\begin{array}{c}2.4 \pm 1.2 \\
(1.4-7.2) \\
\text { Mode }=1.7 \\
\text { Median }=2.0 \\
\mathrm{n}=46\end{array}$ & 3.3 & $\begin{array}{c}133 \pm 4 \\
(126-140) \\
\text { Mode }=133 \\
\text { Median }=133 \\
\mathrm{n}=17\end{array}$ \\
\hline $\begin{array}{l}\text { Male No. } 1 \\
29-30^{\circ} \mathrm{C} \\
\text { in duet }\end{array}$ & $\begin{array}{c}552 \pm 37 \\
(484-638) \\
\text { Mode }=547 \\
\text { Median }=547 \\
\mathrm{n}=31\end{array}$ & $\begin{array}{c}1.7 \pm 0.3 \\
(1.3-2.4) \\
\text { Mode }=\mathrm{N} / \mathrm{A} \\
\text { Median }=1.7 \\
\mathrm{n}=31\end{array}$ & 4.3 & $\sim 140$ \\
\hline
\end{tabular}

closing movement. The sound is produced during the closing of tegmina.

The song frequencies (Fig. 15) are between 15 and 24 $\mathrm{kHz}$, possibly artificially restricted by the low sampling rate $(48 \mathrm{kHz})$, with a maximum of about $21-22 \mathrm{kHz}$.

Variation. As this species only inhabits the subalpine low-vegetation belt and possibly has a quite restricted range, it shows little morphological and bioacoustic variation. However, there is some slight variation in the size of the body parts and sometimes insignificant differences in the shape of the male pronotum. The song may also differ slightly under different conditions (Table 1), such as temperature and male activity.

Material. Holotype $\delta$ (dry preparation; NMNH) (Fig. 8A, C), paratypes: $2 \hat{0}, 2 \uparrow(\mathrm{NMNH}), 9 \hat{0}, 4 \uparrow, 2 \hat{0}$ nymphs last instar, 19 nymph $5^{\text {th }}$ instar, $10^{t}$ nymph $4^{\text {th }}$ instar (CC), 20,2 우 $(\mathrm{CH})$ : Macedonia (FYROM), Struga district, Mt. Jablanica (Yablanitsa), NW of Gorna Belica village: (UTM: 34TDL56) localities around Crn Vrv Peak (Krstec Place), Chuma Peak and Golem Kokal Peak; (UTM: 34TDL66) Vevchansko Ezero Lake; (UTM: 34TDL56/66) Podgorechko Ezero lake; (UTM: 34TDL57/67) Srizhjak peak; above the timberline (Fagus sylvatica), montaneous/subalpine meadows (limestone and siliceous soils), mostly in mesophyte herbaceous thickets, 1800-2100 m alt., 18.-20.vii.2006, leg. D. Chobanov (NMNH).

Etymology. Named after its type locality, Jablanica Mountain.

Distribution (Figs 10,13) and ecology. This species is known from high parts of Jablanica Mountain, above the timberline, at an altitude of 1800-2100 m a.s.l. Here it inhabits lush pseudosubalpine and subalpine meadows with Rumex spp., Rubus idaeus, etc. The animals were relatively abundant and stayed on the vegetation or within it. At the end of July most of the individuals were already adult and sexually active, though at the highest places nymphs still occurred. Around snow patches, where the snow had recently melted, nymphs of all instars, including recently hatched, were found.

Jablanica Mt., together with Korab Mt., forms a small group of young mountains with alpine relief and is part of the 
Southern Dinaric mountain group of the Pindo-Dinaric system. Jablanica is well isolated from the North, East and South by deep river valleys or low passes (lower than $1000 \mathrm{~m}$ a.s.1.), although considering historic events this is not an absolute criterion for isolation. The western crest of Jablanica Mt. (situated in Albania) parallel to the main ridge is well connected not only with Jablanica but also with Chermenika Mt., thus the species range is likely to include also areas in Central Western Albania.

\section{B. Species of the Poecilimon ornatus group known only from Greece}

Systematics and distribution of the Greek species are covered in the papers of F. Willemse (1982, 1985), L. Willemse (1987), F. Willemse \& Heller (1992) and F. Willemse \& L. Willemse (2008). Here only a short summary is given plus some additional new results.

\section{Poecilimon pindos F. Willemse, 1982}

Poecilimon pindos Willemse, 1982 (160-161, Figs 15, 16, 131-133, 187-189, 203, 204), type locality Greece, Pindos Mts, Timfi Mt. above Papikon, 1800-2000 m; Willemse, 1985 (15, Fig. 36); Heller, 1988 (50, Abb. 34-H, 107, 121-B).

This species' cercus shape is shown in Fig. 3P and song in Fig. 7D.

Distribution (Figs 9, 10, Appendix). This species is restricted in its distribution to the Northern Pindos Range in Greece, hitherto only recorded from the high parts of the mountains of Timfi and Mavrovouni, between 1800 and $2100 \mathrm{~m}$ a.s.l.

\section{Poecilimon obesus Brunner von Wattenwyl, 1878}

Poecilimon obesus Brunner von Wattenwyl, 1878 (38), type locality Greece, "Epirus" and "Parnass"; Ramme, 1933 (513, plates 6-2, 8-3, 11-3, 12-3, 3a, 3b); Harz, 1969 (118, Figs 269, 345-348); Willemse, 1982 (161-162, Figs 19-22, 136-138, 207, 208).

Poecilimon beieri Ramme, 1933 (514, Pls 6-4, 8-5, 11-4), type locality Greece, Meganisi Island; Harz, 1969 (120, Figs 272, 320, 350); Willemse, 1982 (162, Figs 23, 209, 210). Synonym of $P$. obesus obesus after Heller (1984).

Poecilimon obesus obesus; Heller, 1984 (77-78, Abb. 3-C, 5-B, 7-B); Willemse, 1985 (15-16, Figs 30, 32); Heller, 1988 (47, Abb. 34-B, 88, 120-B).

This species' general appearance is shown in Fig. 1F, the cercus shape in Fig. 2OB and the song in Fig. 7F.

Distribution (Figs 10, 11, 13, Appendix). This species was obviously misidentified as Polysarcus scutatus by Szijj (1992), which was confirmed by our findings at one of Szijj's localities. Like P. obesus species of the genus Polysarcus also have a very wide fastigium. Polysarcus scutatus is currently known from only one area in Greece (located above $1600 \mathrm{~m}$ a.s.1.; Willeme \& Willemse, 2008).

The range of this species covers the western parts of Central and Northern Greece; recorded on Parnass Mountain by Brunner von Wattenwyl (1878), but not since so this high mountain locality is considered doubtful. The localities in Bosnia and Hercegovina (Mikšić, 1973) in Maglich Mountain are equally doubtful both because of their remoteness from the range of $P$. obesus and their high altitude (see Discussion for the species' ecological preferences). Most probably they are of a taxon related to $P$. ornatus or $P$. affinis. The record of $P$. obesus from Sliven (Central East Bulgaria) (Frey-Gessner, 1893: p. 401 19; Nedelkov, 1908: p. 426 - not clear whether this is quoting information in Frey-Gessner, 1893 or referring to a new
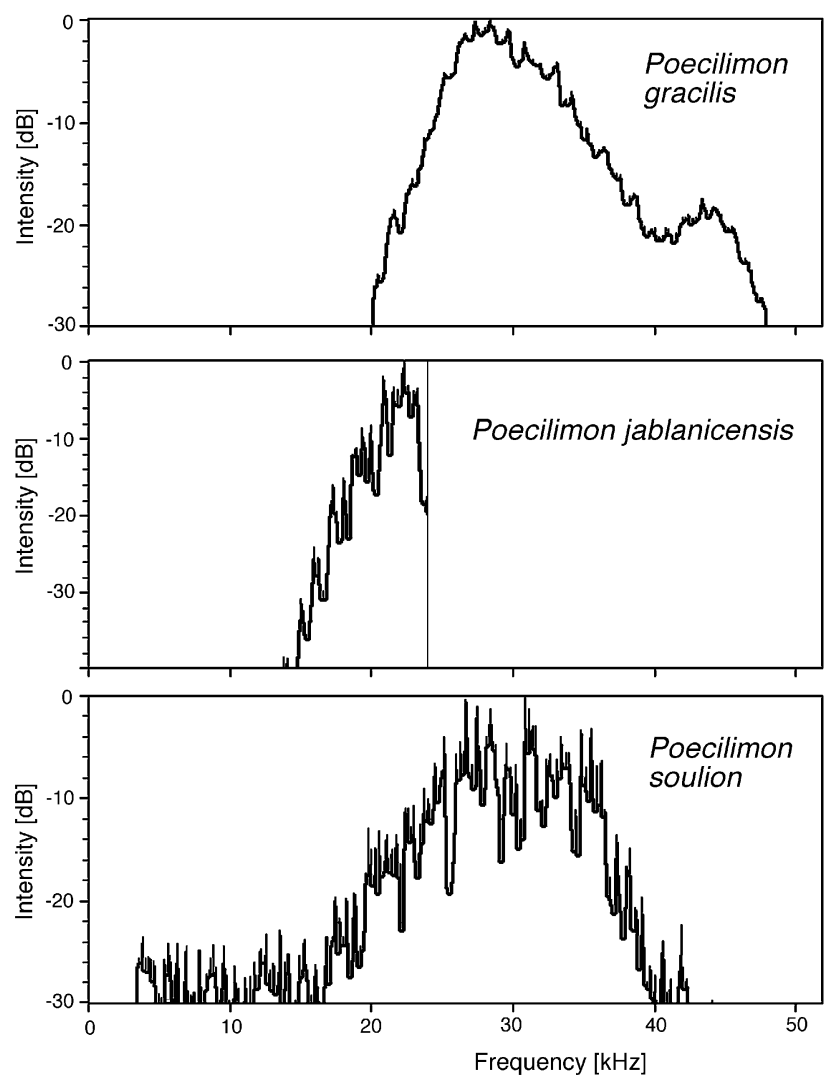

Fig. 15. Frequency spectra of the male calling songs of $P$. gracilis, rec. POGR8905 (CH2555), P. jablanicensis (male No. 2, recorded 7.viii.2006) and P. soulion, rec. POOB8901 (CH2475) (other data as in Fig. 7).

material) cannot be referred to any of the species of this group, both because of its great remoteness from the group's range and the low altitude, until the material is found or more specimens are collected. In contrast to all other species in this group $P$. obesus is found at low altitudes, with many of the localities below $200 \mathrm{~m}$ a.s.l. and never above $1500 \mathrm{~m}$ a.s.l.

\section{Poecilimon artedentatus Heller, 1984}

Poecilimon obesus artedentatus Heller, 1984 (78-79, Abb. 3-D, 4, 5-A, 7-C), type locality Greece, Peloponnes, Akhaia, E of Kato Vlassia vill. (Umg. Metaxion) on the road to Kalavrita, 840 m; Willemse, 1985 (16-17); Heller, 1988 (47, Abb. 34-C, 35-B, 88, 120-A).

Poecilimon artedentatus; Willemse \& Heller, 1992 (301, 303) (stat. n.).

This species' general appearance is shown in Fig. 1G, the cercus shape in Fig.2A and song in Fig. 7E.

Distribution (Figs 10, 13, Appendix). Poecilimon artedentatus is restricted to the Peloponnesos (Greece), where it occurs mainly between 500 and $1000 \mathrm{~m}$ a.s.l. and never above $1500 \mathrm{~m}$ a.s.l.

\section{Poecilimon nobilis Brunner von Wattenwyl, 1878}

Poecilimon nobilis Brunner von Wattenwyl, 1878 (50), type locality Greece, "Athen" and "Taygetes"; Ramme, 1933 (513, Pls 6-3, 8-4, 12-4, 4a); Harz, 1969 (118, Figs 267, 342-344); Willemse, 1982 (162-163, Figs 24-26, 182, 183, 211, 212); Heller, 1984 (76-77, Abb. 3-A, 7-A); Heller, 1988 (46, Abb. 34-A, 35-A, 88, 121-E). 

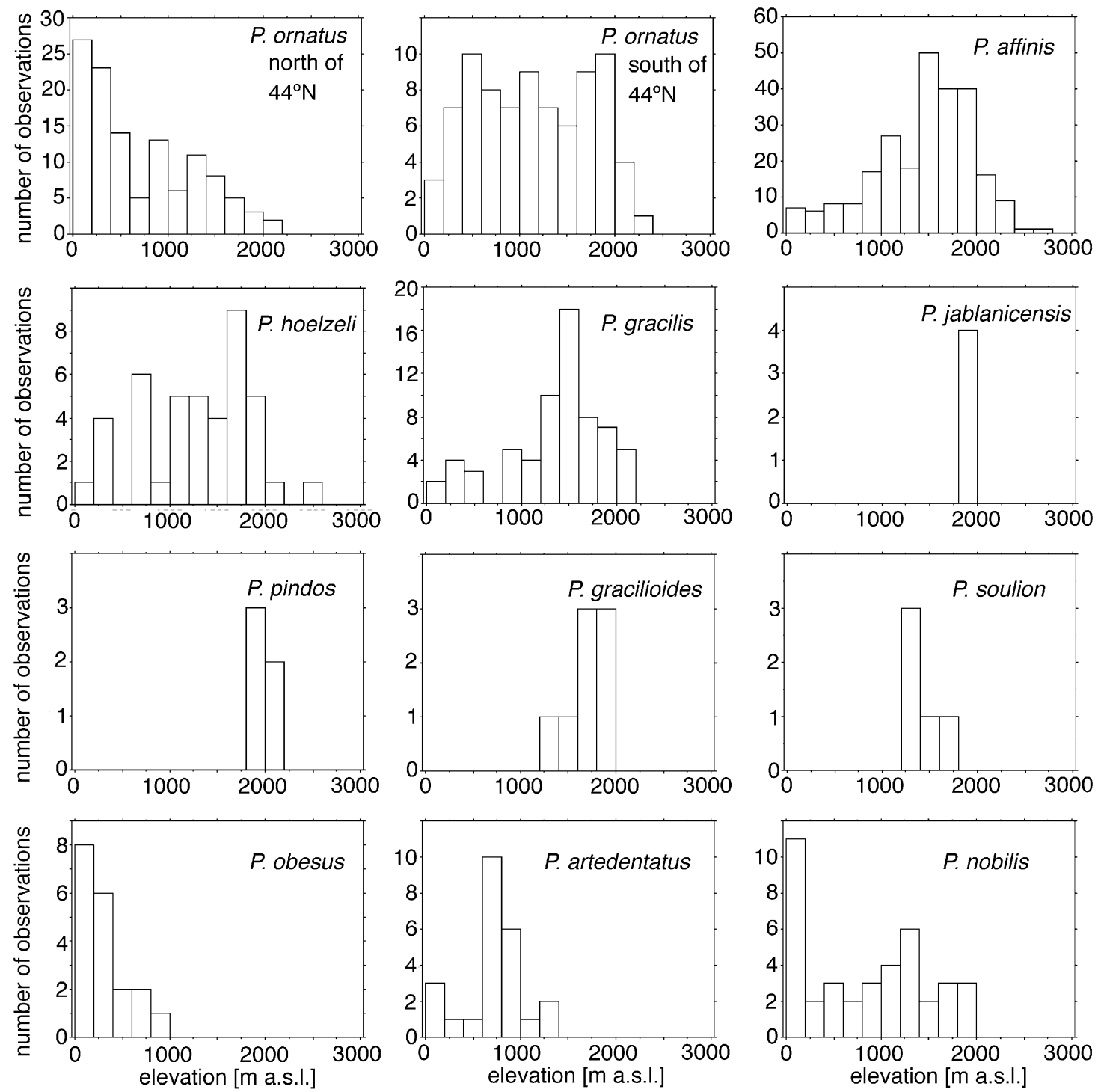

Fig. 16. Altitudinal distribution of the species in the P. ornatus group.

Poeclimon holtzi Werner, 1902 (116, 2 Figs), type locality Greece, Kambos. Synonym of P. nobilis after Werner (1933).

This species' general appearance is shown in Fig. 1H, cercus shape in Fig. $2 \mathrm{~N}$ and song in Fig. $7 \mathrm{G}$.

Distribution (Figs 12, 13, Appendix). Poecilimon nobilis is restricted to the Peloponnesos, where it is found from sea level up to $2000 \mathrm{~m}$ a.s.l. The locality "Athens", mentioned by Brunner von Wattenwyl (1878) as one of the type localities, is considered to be doubtful.

\section{Poecilimon soulion L. Willemse, 1987}

Poecilimon soulion L. Willemse, 1987 (173-177, Figs 1-8, 10, 14, 17); Heller, 1988 (51, Abb. 121-D, F); Willemse \& Heller, 1992 (303, Fig. 11).

This species' cercus shape is shown in Fig. 2S1, S2.

Bioacoustics. The male's calling song (Figs 7H, I, 14B) consists of single syllables, usually repeated irregularly. The song of a topotypical male (Figs 7H, 14B) recorded at $20^{\circ} \mathrm{C}$ at $10: 30 \mathrm{~h}$ when it was sunny and at $29^{\circ} \mathrm{C}$ at $18: 30 \mathrm{~h}$ was similar (possibly the body temperature of the animal at $20^{\circ} \mathrm{C}$ was higher as it was lit by the sun). At $20^{\circ} \mathrm{C}$ the syllable duration was $466-617 \mathrm{~ms}$ (mean $531 \pm 43, \mathrm{n}=18$ ) and the syllable period 4.4-15.5 s (mean $7.9 \pm 3.4, \mathrm{n}=17$ ). At $29^{\circ} \mathrm{C}$ the syllables lasted 331-407 ms (mean $368 \pm 33, \mathrm{n}=5$ ), the syllable period $6.3-9.8 \mathrm{~s}$ (mean $7.8 \pm 1.5, \mathrm{n}=4$ ). In the song of the male from Central Greece (Fig. 7I) the mean syllable duration was $546 \mathrm{~ms}$ and mean syllable period $16.4 \mathrm{~s}(\mathrm{n}=4 / 3 ; \mathrm{T}=$ $\left.26.5^{\circ} \mathrm{C}\right)$.

The syllable consists of three parts. The first part consists of about 30 to 80 irregularly arranged low amplitude impulses with an impulse period of $1-3$ to $15 \mathrm{~ms}$. The second part follows without interruption and has 5-10 high-amplitude impulses, produced at longer intervals of $15-60 \mathrm{~ms}$. After a silent interval of $30-70 \mathrm{~ms}$ the second part is followed by the third part, consisting of 15-30 densely arranged impulses with an impulse period of 2-4 ms (measurements mostly on the topotypical male). The peak of the frequency spectrum (male from Central Greece) occurs at about $30 \mathrm{kHz}$ (Fig. 15).

Distribution (Figs 12, 13, Appendix). This species does not only occur on the mountains of Soulion and Tomaros in 
Western Continental Greece, but also in Central Greece, always at altitudes of between 1200 to $1900 \mathrm{~m}$ a.s.l. The specimen from Central Greece clearly differs in pronotum, cerci (Fig. 2S2) and song (Fig. 7I) from $P$. gracilioides, the main range of which is closer than that of the typical $P$. soulion.

\section{Poecilimon gracilioides Willemse \& Heller, 1992}

Poecilimon gracilioides Willemse \& Heller, 1992 (303-305, Figs $1-5,12,24,30)$, type locality Greece, Arta, Tsoumerka Mt., S of Theodoriana, 1400-1800 m.

This species' general appearance is shown in Fig. 1I, cercus shape in Fig. 2G1, G2 and song in Fig. 7J.

Distribution (Figs 12, 13, Appendix). This species has a restricted range occurring on a few summits in Western Continental Greece, in particular the Tsoumerka, Chatzi, Avgo, Karava, Voutsinaki and Kakardhitsa Mts, between 1350 and $1850 \mathrm{~m}$ a.s.l.

\section{Composition of the Poecilimon ornatus group and recognition of the taxa}

The group includes 14 valid taxa, 2 of which are doubtful (32 described forms), belonging to 11 species: $P$. ornatus, $P$. affinis affinis, $P$. affinis komareki, two taxa with doubtful status: $P$. affinis serbicus and $P$. affinis hajlensis, $P$. hoelzeli, $P$. artedentatus, $P$. obesus, $P$. nobilis, $P$. pindos, $P$. soulion, $P$. gracilioides, $P$. gracilis and $P$. jablanicensis. Recognition of the relevant taxa, i.e., excluding $P$. affinis serbicus and $P$. affinis hajlensis, is given in Table 2 .

\section{DISCUSSION}

\section{Phylogeny of the Poecilimon ornatus group and affinities between its taxa}

Variation within the group, especially the autapomorphies of $P$. jablanicensis, which are convergent with those of other species within the genus, makes the definition of the main characteristics of this group difficult. However, the plesio-/apomorphic state of some features of the species makes it possible infer some intragroup relationships.

I. Basal taxon. Poecilimon gracilis appears to be morphologically and bioacoustically the most primitive species in the $P$. ornatus group, indicating its connection with other species of the genus (cf. Heller, 1984) and thus is basal to the other taxa and a sister taxon to the hypothetical ancestor of this group. This view is supported by molecular data (Ullrich et al., 2010), where in a tree based on mt-DNA sequences (see Ullrich et al., 2010: Fig. 3B) $P$. gracilis also occupies the most basal position. However, its position in this tree is statistically not well supported as it is the same as that of the other basal species of this branch, which do not seem to belong to the $P$. ornatus group for biogeographical and morphological reasons. The shape of the pronotum and body size of $P$. gracilis are similar to those of two taxa with unclear positions, $P$. thoracicus (Fieber, 1853) and P. schmidtii (Fieber, 1853). However, the song structure of $P$. gracilis differs from these species in having much longer syllables, temporarily separated in the first and longer part of detached impulses, followed by a second louder and shorter part of more frequent impulses. This type of song is produced by species in one of the main stems of the group, although the transition from bipartite to compact syllable consisting of many impulses appears to have evolved independently at least three times within this group.

II. Southern stem. Two complexes are included here. $P$. gracilioides and $P$. soulion form the first complex, well supported by both mt- and nucleolar-DNA-data (Ullrich et al., 2010). They are morphologically similar to $P$. gracilis and distributed south of its range. In their song, there is an additional part of frequent and low-amplitude impulses, which tripartitions the song. The second complex, also well supported by mt-DNA-data (Ullrich et al., 2010), P. nobilis, P. obesus and $P$. artedentatus, occupy the southernmost range of the group, occurring in Southern Continental Greece, including the Peloponnesos. These species are morphologically similar, but $P$. artedentatus has a song consisting of compact syllables, similar to that of $P$. affinis, $P$. hoelzeli, $P$. pindos and $P$. jablanicensis.

III. Northern stem. Four sibling species form this stem: P. pindos, P. hoelzeli, P. affinis and P. ornatus. While the stem itself is well supported by mt-DNA-data, the relationships within it are not well resolved and the molecular data are partly contradictory (Ullrich et al., 2010). Although morphologically $P$. pindos shows some similarity with the smaller representatives in the southern stem, generally the species in this stem have much more pronounced apomorphies. These include cerci with pointed tips, but lacking a detached tooth and a song consisting of compact syllables made up of many impulses. Additionally, this species is characterized by a large body size and a low-frequency song. In $P$. ornatus the syllables are secondarily shortened, which is associated with morphological specialization of the stridulatory row (see under this species).

This stem is probably of relatively recent origin and connected historically with that of the Balkan mountain ranges. $P$. affinis and $P$. ornatus have the widest distribution within this group. Both species do not occur further south than Northwestern Greece (northernmost part of the Pindos range) but spread far northwards through the central and western parts of the Balkan Peninsula up to the Southeastern Alps (P. ornatus) and the Northeastern Carpathians ( $P$. affinis). $P$. hoelzeli and $P$. pindos have much more restricted ranges in the mountains of Northern Greece and neighbouring territories.

IV. Species Poecilimon jablanicensis. Morphologically $P$. jablanicensis is closest to $P$. gracilis. Due to many autapomorphies (small auditory spiracle, squamipterous females, continuous syllables, arranged in fast sequences, low-frequency song) it is considered separately. However, this species occurs parapatrically with $P$. gracilis and may have evolved by rapid speciation after recent separation from the latter or from a gracilis-like ancestor of both species.

On the basis of morphological and behavioural characteristics, the following phylogenetic relationships within 
the group are suggested: $[(P$. gracilis, $P$. jablanicensis $)$, ((P. gracilioides, P. soulion), ( $P$. nobilis, $(P$. obesus, $P$. artedentatus $))),(((P$. pindos, $P$. hoelzeli $), P$. affinis $), P$. ornatus)].

The characteristics of the group may be summarized as follows:

1. Metazona of pronotum with a tendency to be raised and broad. This character is differently exhibited in the taxa (see Table 2) and may even depend on climatic conditions and population-size (Karaman, 1974) (see below).

2. Metazona of pronotum elongated. This character is found in other species groups, e.g. the Poecilimon heroicus group, but is not present in the basal taxon $P$. gracilis.

3. Auditory spiracle large and wide open. This character is found in many groups of the genus; as an autapomorphy within the group in $P$. jablanicensis the spiracle is smaller.

4. Massive cerci with a single detached tooth or pointed tip (also found in other species groups of Poecilimon).

5. Song consisting of single syllables with a duration usually between 100 and $1000 \mathrm{~ms}$, with the exception of $P$. ornatus, where secondarily the first part of the syllable is reduced and the latter distinctly shorter than $100 \mathrm{~ms}$.

6. Spines on ventral edge of hind femora: present in all large species including $P$. soulion, but tend to be lost or fewer in number in $P$. gracilis (only one spine in some populations: some specimens lack spines (Heller, 1984)), P. jablanicensis (does not posses spines) and $P$. graciliodes (occasionally there is one spine on both or one of the femora).

\section{Biogeography and ecology of the Poecilimon ornatus group}

The present-day distribution of species of the Poecilimon ornatus group has an interesting "patchy" pattern in the Balkans, which is a result of para- or allopatric speciation and, in some taxa, numerous subsequent vertical and horizontal shifts in range.

This group probably originated in the Southern Balkans, where most species with primitive morphological and bioacoustic characters occur. Spreading to the North was realized by two groups: $P$. gracilis and $P$. ornatus/affinis. $P$. gracilis and $P$. ornatus took mainly a western route, occurring often sympatrically and even syntopically (compare Figs 10 and 12 with Figs 11 and 13). The most western point reached by $P$. ornatus is Trentino in Italy. $P$. affinis spread towards the east reaching as far as Kanev in the Ukraine. However, in the south $P$. gracilis occurs sympatrically not only with $P$. ornatus, but more often with $P$. affinis, indicating spread by different paths. In fact, the only reliable cooccurrences of $P$. gracilis and $P$. ornatus are in the northwestern part of their ranges in Slovenia and Southern Austria, and the southern slope of the Jakupica Mountains in Central Macedonia (see Figs 10, 11, 12, 13). It is difficult to hypothesize about the spread of $P$. ornatus and $P$. affinis because the distribution records for $P$. ornatus/affinis North of Macedonia and Bulgaria up to Slovenia are unreliable. However, their distribution in the southern part of the range (Fig. 11) indicates that the dispersal of these species followed a complex pattern but that probably after allopatric speciation the ranges overlapped. Interestingly, ranges of mountains are mostly occupied by one of these species, with only very few exceptions (e.g. Bulgaria: Northern Pirin Mts). Future detailed studies in less well studied areas like Albania are likely to prove very informative.

Most other taxa seem to have retained an endemic state, failing to expand their original range to any great extent. Generally, there are very few localities known with syntopic occurrence of two species of the group (except of $P$. gracilis with $P$. ornatus or $P$. affinis): $P$. affinis and $P$. hoelzeli in the mountains of Pieria and Olympus in Greece (Willemse, 1985; F. Willemse, in litt.); P. affinis and $P$. pindos on Mavrovouni Mt. $\mathrm{N}$ of Metsovon, Ioannina, Greece (Willemse, 1982 as $P$. ornatus and $P$. pindos; cf. Willemse, 1985); P. affinis and P. jablanicensis in the (pseudo-) subalpine belt on Jablanica Mt. (Albanian-Macedonian border), Macedonia (pers. observations); $P$. ornatus and $P$. hoelzeli in the pseudosubalpine meadows along the ridge of the Belassitsa Mountain (Bulgarian-Greek border), Bulgaria (pers. observations); $P$. ornatus and P. obesus near Kouklii, Ioannina, Greece (pers. observations); P. ornatus and $P$. gracilioides on Tsoumerka Mountain, Arta, Greece (pers. observations); $P$. nobilis and $P$. artedentatus on Mikinai, Argolis, Greece (leg. E. Blümm) and Langadia, Arkadhia, Greece (leg. B. Grzywacz).

The distibutions of these species seem to indicate competitive exclusion, either because of their behaviour or ecology. It is difficult to argue for both. Their calling songs should differ enough to allow the coexistence of at least some species combinations, although the females of $P$. ornatus are quite unselective (Heller et al., 1997). In terms of ecology, there are no obvious differences between the species. However, three groups, generally differing in their habitat- and/or altitude preferences (Fig. 16), can be distinguished.

First group includes the widely distributed species $P$. affinis, P. ornatus and $P$. gracilis. $P$. hoelzeli, though having a comparatively restricted distribution, may also be included in this group. These species have a preference for high altitudes (as do some other less widespread species), but $P$. ornatus has a less restricted distribution than the other three, occurring in the lowlands (Slovenia) and from about $300-500 \mathrm{~m}$ in Bulgaria and Macedonia up to 2400-2450 $\mathrm{m}$ in the Pirin Mts (see Fig. 16). In the North, $P$. ornatus, $P$. affinis and $P$. gracilis seem to prefer lower altitudes than in the South. For example, $P$. affinis in Ukraine is found in low hills and in Romania it is most common between 900 and $1000 \mathrm{~m}$ (Kis, 1962). In the South it is commonly found between 1000 and $2000 \mathrm{~m}$, and up to $2400-2450 \mathrm{~m}$ in the southernmost areas. $P$. gracilis is sometimes found at low altitudes in the North, while in the South it usually inhabits the beech forest-belt, reaching up to $2250 \mathrm{~m}$. P. hoelzeli is found usually in the subalpine belt but ranges from 100-200 up to $2400-2450 \mathrm{~m}$. 
A common feature of all four species is the high morphological variability (see under each species). Karaman (1974) argues that microclimate and population density are important factors connected with the morphology. At high altitudes the specimens are darker in colour, smaller (except sometimes the tegmina, which are the same size and thus the ratio of the size of body to tegmina changes) and have a steeply upcurved pronotum. This is especially true of the populations of $P$. affinis and $P$. hoelzeli at the upper limit of their distributions, while such a tendency is less obvious in $P$. gracilis. A similar tendency is observed at high population densities, both at high and low altitudes. A striking example is the high density populations of $P$. ornatus at low altitudes in Macedonia and Bulgaria, where the aggregations of nymphs resemble the swarms recorded in other Barbitistinae species (e.g. Isophya speciosa, Polysarcus denticauda) (Kis \& Privescu, 1966; Hartley, 1986). These animals are almost completely dark coloured (see Fig. 1K).

The second group includes some species with restricted distributions in an area south of the range of the first group. The species are $P$. pindos, $P$. soulion, $P$. gracilioides and $P$. jablanicensis. These are intermediate between the first and the third group in occurring mostly in the mountain/subalpine belt between 1500 and $2100 \mathrm{~m}$. $P$. soulion is closer to the third group in occurring at altitudes down to $1200 \mathrm{~m}$. These species show little variation in morphology and poor dispersal ability, possibly because they are adapted to a comparatively constant microclimate.

The third group includes the three southern species, $P$. nobilis, $P$. artedentatus and $P$. obesus. $P$. nobilis occurs up to $2000 \mathrm{~m}$ without any obvious altitude preference, with a peak occurence at $0-200 \mathrm{~m}$. This peak could be an effect of the accessibility of the localities and relative size of the area, with the result that lowland populations are much more frequently sampled. $P$. artedentatus seems to be a colline species occuring mainly between 500-1000 $\mathrm{m}$. P. obesus is active early in the season and has a strong preference for lowlands.

It is interesting to consider the distribution of these three groups during the ice ages. During the PliocenePleistocene the alternating warming and cooling periods resulted in changes in the altitudinal distribution of the climatic and vegetation belts. For example, in the Rila Mountains (Bulgaria), the treeline limit changed from $2300 \mathrm{~m}$ about $6700-6500 \mathrm{BP}$ to $1100-1300 \mathrm{~m}$ in the coolest periods about 18000 BP (e.g. Tonkov \& Marinova, 2005). The Poecilimon species, which are mostly tolerant of moderate temperatures and connected with mesophyte vegetation and humid microclimates, could have shifted their ranges towards lower altitudes in the cool periods. The problem would have been finding appropriate humid habitats, since glacial maxima are connected with a lowering of athmospheric humidity and increase in the distribution of xeric grass communities. Though the lower temperatures would have allowed coldclimate adapted species to populate lowlands, mesophile animals would not have been able to colonize the xero- phytic grassy habitats. Thus, the species may have been isolated in small populations in areas with the appropriate microclimate. The temperature maxima during the interglacials caused animals to move to higher altitudes (alternative to local extinction) and thus the cold adapted species may have been isolated in the so called "sky islands" (Knowles, 2000, 2001). Therefore, both cooling and warming periods may have promoted speciation within this group.

\section{Bioacoustics of the Poecilimon ornatus group}

Based on morphological (Heller, 1984; present paper) and molecular (Ullrich et al., 2010) data it is suggested that the basal taxon of this group is similar to $P$. gracilis. Thus, the ancestral song may have had a structure similar to that of $P$. gracilis and its closest relatives. At least, no other type of song has more plesiomorphic characters. This song is quite specialized, consisting of single long syllables, temporarily separated into two parts (bipartite song) (see above). Similar syllables and stridulatory movements are also recorded e.g. in the $P$. sanctipauli group (Heller \& Sevgili, 2005). This type of song (Type I) is present also in $P$. obesus and $P$. nobilis, while in the other species the syllable has undergone evolution in two directions resulting in three other types of song. It is, however, not clear whether the similar song pattern in $P$. obesus and $P$. nobilis represents the ancestral state or is a result of convergence. In all these species the closing movement begins quite slowly and changes abruptly at the end but there are no obvious modifications of the stridulatory file (Heller, 1988).

Type II. By a minor modification the song becomes tripartite. This may have occured simply by retaining the movement pattern of $P$. gracilis and using a larger part of the file or additionally by increasing the speed of the beginning of the stridulatory movement and slowing down the closing movement of the tegmina. This type of song is characteristic of $P$. soulion and $P$. gracilioides. Both species have a stridulatory file with an abrupt change in tooth size (see Willemse, 1987; Willemse \& Heller, 1992).

Type III. The characteristic of this type of song is that the first and second parts of the type I-syllable merge, which is achieved by a transition from an interrupted to uninterrupted stridulatory movement (closing) of the tegmina. As a result, a compact syllable consisting of a crescendo of many impulses developed. Interestingly this type of song has obviously developed independently three times: in $P$. artedentatus in the Southern stem; in $P$. pindos/hoelzeli/affinis in the Northern stem and in $P$. jablanicensis. Except for $P$. pindos, all these species have quite high numbers of stridulatory teeth. An initial stage of type III is observed in P. artedentatus where the transition from the first to the second part of the syllable is very sharp and sometimes even marked by a few sparse impulses (see Fig. 7E). This type of song is typical of species in the Northern stem (except for P. ornatus), where the syllable is quite compact but both parts are easily recognizable. 
$P$. jablanicensis is an exception as it probably evolved directly from $P$. gracilis (see below). Though it morphologically clearly resembles the latter, the song of $P$. jablanicensis is more highly differentiated within type III in having a smooth transition from low- to highamplitude impulses. In additon, the high-amplitude part is much longer than in all the other species in the group, probably because it is not the trigger for the timing of the acoustical response of the female. Its similarities to $P$. gracilis in "non-acoustical" morphology and restricted range, parapatric to that of $P$. gracilis, are thought to be a consequence of a comparatively rapid speciation of $P$. jablanicensis. Heller et al. (2008) observed that the morphological evolution, especially that of the male genital structures, typically occurs faster than the evolution of song characters. In contrast, the speciation of $P$. jablanicensis involved unusually fast changes in both the song and the "acoustical" morphology as a consequence of the change in the communication system.

Type IV. P. ornatus shows another stage in the differentiation. Being clearly a representative of the Northern stem, its song evolved by reducing the low-amplitude first part of the type III-syllable. This is achieved both physiologically by shortening the closing stridulatory movement and morphologically by developing a fold in the distal part of the stridulatory row. This species is also characterised by very poor specific song recognition by the female (Heller et al., 1997).

Of special interest is the repeated "compactization" of the syllables in the male calling song, which occurs three times within this species group (see above). It may be connected with the advantages of louder and far reaching signals, since in the neuronal system close impulses may increase the loudness if they fall within the female integration time. Still, this phenomenon cannot be easily explained and may have a different cause in each case. Nevertheless, it is interesting to discuss the specializations in the song of $P$. jablanicensis, the most peculiar species in the P. ornatus group.

Poecilimon jablanicensis probably evolved on a restricted range of mountain summits from an isolated population of $P$. gracilis or a gracilis-like ancestral form. This could be inferred by its resemblance to the latter and the autapomorphies within this group. These are a result of specialization, involving the secondary development of a unidirectional acoustic communication system.

This is the only known example within the $P$. ornatus group where females lost the ability to answer males. The loss of bidirectional communication may be connected with the need to produce an easily recognizable and traceable call. This is achieved by using long sequences of frequently repeated simple syllables, with high intensity and low frequency maximum, a phenomenon recorded for other Poecilimon species with a unidirectional communication system (Heller \& Lehmann, 2004; Heller et al., 2006). The lower frequency maximum of the song is typically connected with a larger body size. P. jablanicensis is the smallest species within the group with song frequencies ranging from 15 to at least $24 \mathrm{kHz}$ and a fre- quency peak at about $21-22 \mathrm{kHz}$, thus the frequency properties of the song are similar to those of the much bigger $P$. nobilis, $P$. artedentatus and P. ornatus (cf. Heller, 1984, 1988). The song of the related $P$. gracilis (comparatively small species) has a much higher frequency range (carrier frequency in the range $24-36 \mathrm{kHz}$ after Heller, 1988; see also Fig. 15). Interestingly, another representative of the group with moderate body size, $P$. pindos, has a quite low frequency range $(12-24 \mathrm{kHz})$ with the maximum at about $15 \mathrm{kHz}$. In both $P$. jablanicensis and $P$. pindos the lowering of the song frequency is achieved by increase in the size of the tegmina and widening and uplifting of the metazona on the pronotum.

The low frequency sounds spread over a greater distance than high frequency sounds. Heller et al. (2006) proposed two hypotheses to account for the development of a low-frequency song - an adaptation to inhabiting dense vegetation or sexual selection. Occurring in a habitat with dense but not high vegetation, $P$. jablanicensis would not need a low-frequency song. However, having evolved in a mountain environment with frequent winds and an unstable microclimate could have led to the need for a reliable and fast mechanism of finding a partner under such conditions.

Interestingly, $P$. jablanicensis also has reduced auditory spiracles and they are exclusively and without exception found in all species of Poecilimon with unidirectional communication. This reduction (together with the fact that the females do not respond acoustically) must thus have ocurred at least three times independently within Poecilimon. The reasons for this reduction and its association with a change in female behaviour are still unclear. Here, the reduced auditory spiracle is assumed to be a result of the need to protect it against physical factors that affect hearing ability, such as wind, but this is not obvious in the other cases. Due to the clear phylogenetic relationships with other species, $P$. jablanicensis seems to be a very suitable species for studying other factors that may have influenced this change, like predation pressure, operational sex ratio, population density or duration of the mating season. For some of these factors there is data for closely related species (Heller \& Helversen, 1991; Heller, 1992).

ACKNOWLEDGEMENTS. We kindly acknowledge the collectors who donated their specimens. We owe special thanks to M. Volleth and M. Ilieva for their help in the field, W. Schulze for the microphone tests, L. Stefanov, A. Ignatov and M. Langourov for providing some of the photographs, the Macedonian Ecological Society and the Biology Students' Research Society (Faculty of Natural Sciences and Mathematics, Skopje) for their regular invitations since 1999 to organize field trips in Macedonia, which resulted in the collection of many specimens of Poecilimon, including the new species, $P$. jablanicensis. For the linguistic correction of the manuscript thanks are due to $\mathrm{S}$. Patchedjiev and the anonymous language editor of EJE. The study was partly supported by grants DO-02-259/08 and DO-02270/08 (Ministry of Education, Youth and Science of Bulgaria, NS Fund). The preparation and publishing of the manuscript was financed by grant BG051PO001-3.3.04/41 (European 
Social Fund through the Ministry of Education, Youth and Science of Bulgaria).

\section{REFERENCES}

Bey-Bienko G.YA. 1954: Orthoptera. Vol. II, Sect. 2. Leaf bushcrickets (Phaneropterinae). In Fauna of the USSR, New Series, 59. Zoological Institute of the Academy of Sciences of the USSR, Sankt Peterburg, $385 \mathrm{pp}$.

BrunNer von Wattenwyl C. 1878: Monographie der Phaneropteriden. Brockhaus, Wien, 401 pp.

Č́JChan A. 1957: Über eine neue Art der Gattung Poecilimon Fisch. aus Albanien (Orthoptera: Tettigoniidae). Acta Entomol. Mus. Nat. Pragae 2: 5-8.

Ciplak B., Willemse F., Chobanov D. \& Heller K.-G. 2007: Systematic status and distribution of Eupholidoptera (Orthoptera: Tettigoniidae) in the Balkans (north of Central Greece). Articulata 22: 33-46.

EAdes D.C. \& Otte D. Orthoptera Species File Online. Version 2.0/3.5. <http://orthoptera.speciesfile.org>. (accessed 10.01. 2010).

EBNER R. 1908: Beiträge zur Orthopterenfauna Bosniens und der Herzegowina. Verh. Zool.-Bot. Ges. Österreich (Wien) 58: 329-339.

FIEBER F.X. 1853: Synopsis der europaischen Orthopteren mit besonderer Rücksicht der Böhmischen Arten. Lotos (Prag) 3: 90-104, 115-129, 138-154, 168-176, 184-188, 201-207, 232-238, 252-261.

Frey-Gessner E. 1893: Orthoptern [sic], gesammelt in Bulgarien von Hrn. Prof. Dr. A. Forel. Mitt. Schweiz. Entomol. Ges. 8: 397-403.

FrIVALDSZKY J. 1867: A magyarországi egyenesröpüek magánrajza [Monographia Orthopterorum Hungariae]. E. Gusztavnal, Pest, 201 pp. [in Hungarian].

SCHEIDER A.: GPSVisualizer online <www.gpsvisualizer.com> (accessed 11.01.2010).

Hartley J.C. 1986: Melanisation in the bush-cricket Polysarcus (Orphania) denticaudus (Charp.) (Orth., Tettigoniidae). Entomol. Mon. Mag. 122: 1-3.

Harz K. 1966: Neues von europäischen Orthopteren. Mitt. Dt. Entomol. Ges. 25: 21-24.

Harz K. 1969: Die Orthopteren Europas 1. Series entomologica 5. Dr. W. Junk N.V., The Hague, 749 pp.

Harz K. 1977: Eine neue Poecilimon-Art aus Jugoslawien. Articulata 1: 27-28.

Heller K.-G. 1984: Zur Bioakustik und Phylogenie der Gattung Poecilimon (Orthoptera, Tettigoniidae, Phaneropterinae). Zool. Jb. Syst. 111: 69-117.

Heller K.-G. 1988: Bioakustik der europäischen Laubheuschrecken. Josef Margraf, Weikersheim, $358 \mathrm{pp}$.

Heller K.-G. 1992: Risk shift between males and females in the pair-forming behavior of bushcrickets. Naturwissenschaften 79: 89-91.

Heller K.-G. \& Helversen D. von 1991: Operational sex ratio and individual mating frequencies in two bushcricket species (Orthoptera: Tettigonioidea, Poecilimon). Ethology 89: 211-228.

Heller K.-G. \& Lehmann A. 2004: Taxonomic revision of the European species of the Poecilimon ampliatus-group (Orthoptera: Phaneropteridae). Mem. Soc. Entomol. Ital. 82: 403-422.

Heller K.-G. \& Sevgili H. 2005: Systematics and bioacoustics of the Poecilimon sanctipauli-group (Orthoptera: Tettigonioidea: Phaneropteridae). Eur. J. Entomol. 102: 265-277.

Heller K.-G., Helversen O. von \& Sergejeva M. 1997: Indiscriminate response behavior in a female bushcricket: sex role reversal in selectivity of acoustic mate recognition? Naturwissenschaften 84: 252-255.

Heller K.-G., Korsunovskaya O.S., Sevgili H. \& Zhantiev R.D. 2006: Bioacoustics and systematics of the Poecilimon heroicus-group (Orthoptera: Phaneropteridae: Barbitistinae). Eur. J. Entomol. 103: 853-865.

Heller K.-G., Sevgili H. \& Reinhold K. 2008: Bioacoustics and systematics of the species of the Poecilimon syriacus group (Orthoptera, Tettigonioidea, Phaneropteridae). Insect Syst. Evol. 39: 361-379.

Karaman M.S. 1958: Neue Orthopteren-Arten aus Jugoslawien, insbesonders aus Mazedonien. Bioloski Glasnik 11: 35-44.

KaRAMAN M.S. 1972: Nouvelle sou-espèce de sauterelle Poecilimon komareki rumijae n.sp. (Orthopt. Phaneropterinae). Bull. Soc. Entomol. Mulhouse 1972: 10-12.

Karaman M.S. 1974: Beitrag zur Kenntnis der Art Poecilimon affinis (Friv.) (Orthoptera, Phaneropteridae). Reichenbachia 15: $23-31$.

Kis B. 1962: Adatok a Romániában elöforduló Poecilimon Fisch. fajok ismeretéhez. (Zur Kenntnis der in Rumänien vorkommenden Poecilimon Fisch.-Arten.) Folia Entomol. Hung. 15: 117-139.

KIS B. \& PIRVESCU D. 1966: Contributii la cunoasterea daunatorului forestier Isophya speciosa Friv. (Orthoptera). Studia Univ. Babez-Bolyai (Ser. Biol.) (Cluj) 2: 77-85.

KNowles L.L. 2000: Tests of Pleistocene speciation in montane grasshoppers (Genus Melanoplus) from the sky islands of western North America. Evolution 54: 1337-1348.

Knowles L.L. 2001: Did the Pleistocene glaciations promote divergence? Tests of explicit refugial models in montane grasshoppers. Mol. Ecol. 10: 691-701.

KöHLER G. 1988: Zur Heuschreckenfauna (Saltatoria) des PirinGebirges (VR Bulgarien). Entomol. Nachr. Ber. 32: 77-80.

MIKšIĆ S. 1973: Die Orthopterenfauna der Gebirge Maglic, Volujak und Zelengora. Wiss. Mitt. Bosnisch. Herzegowin. Landesmus. (Sarajevo) 3: 145-159.

Nedelkov N. 1908: [Second contribution to the entomological fauna of Bulgaria]. Periodichesko Spisanie na Bulgarskoto Knizhovno Druzhestvo v Sofia [Periodical Journal of the Bulgarian Literary Society in Sofia] 19: 411-436 [in Bulgarian].

Pavićević D. \& Karaman I. 2001: New evidence concerning Orthoptera of Serbia with reflection on the previously listed species (Insecta, Orthoptera). Zastita Prirode (Belgrade) 52: 23-33 [in Serbo-Croatian, English abstr.].

Peshev G. 1980: A contribution to the taxonomy of the genus Poecilimon Fisch. (Orthoptera, Tettigoniidae). Acta Zool. Bulgar. 16: 30-43.

RAMmE W. 1933: Beiträge zur Kenntnis der palaearktischen Orthopterenfauna (Tettig. et Acrid.). II. Mitt. Zool. Mus. Berlin 18: 416-434.

RAmme W. 1951: Zur Systematik, Faunistik und Biologie der Orthopteren von Südost-Europa und Vorderasien. Mitt. Zool. Mus. Berlin 27: 1-432.

Schmidt F.J. 1850: Insekten der Krainer Alpen. Ber. Mitt. Freund. Naturwiss. Wien 6: 182-184.

StumpNer A. \& Heller K.-G. 1992: Morphological differences of the auditory system in three related bushcrickets (Orthoptera: Phaneropteridae, Poecilimon). Physiol. Entomol. 17: 73-80.

SzIJj J. 1992: Ökologie der Heuschrecken in den Flussmündungen Griechenlands im Zusammenhang mit der landschaftsökologischen Entwicklung (Orthoptera: Saltatoria). Dt. Entomol. Z. 39: 1-53.

Tonkov S. \& Marinova E. 2005: Pollen and plant macrofossil analyses of radiocarbon dated mid-Holocene profiles from 
two subalpine lakes in the Rila Mountains, Bulgaria. The Holocene 15: 663-671.

Ullrich B., Reinhold K., Niehuis O. \& Misof B. 2010: Secondary structure and phylogenetic analysis of the Internal Transcribed Spacers 1 and 2 of bush crickets (Orthoptera: Tettigoniidae: Barbitistini). J. Zool. Syst. Evol. Res. 48: 219-228.

WERNER F. 1902: Beiträge zur Kenntnis der Orthopterenfauna Griechenlands. Berl. Entomol. Z. 47: 111-118.

WerNER F. 1933: Über Orthopteren aus Ost-Griechenland und von den Inseln des Ägäischen Meeres. Mitt. Zool. Mus. Berl. 18: $395-415$.

WiLlemse F. 1982: A survey of the Greek species of Poecilimon Fischer (Orthoptera, Ensifera, Phaneropterinae). Tijdschr. Entomol. 125: 155-203.

Willemse F. 1984: Catalogue of the Orthoptera of Greece I. Fauna Graeciae 1, Helenic Zoological Society, Athens, 275 pp.
Willemse F. 1985: Supplementary Notes on the Orthoptera of Greece Ia. Fauna Graeciae 1a., Hellenic Zoological Society, Athens, $47 \mathrm{pp}$.

WILLEMSE L. 1987: Poecilimon soulion sp. nov., a new bushcricket from Greece (Orthoptera: Phaneropterinae). Entomol. Ber. Amsterdam 47: 173-177.

WiLlemse F. \& Heller K.-G. 1992: Notes on systematics of Greek species of Poecilimon Fischer, 1853 (Orthoptera: Phaneropterinae). Tijdschr. Entomol. 135: 299-315.

WiLlemse F. \& WiLlemSE L. 2008: An annotated checklist of the Orthoptera-Saltatoria from Greece includig [sic] an updated bibliography. Articulata 13: 1-91.

Received February 1, 2010; revised and accepted April 22, 2010

APPENDIX ONLINE:

$<$ http://www.eje.cz/supplfiles/eje1575suppl.pdf> 